Article

\title{
Dual Geochemical Characteristics for the Basic Intrusions in the Yangtze Block, South China: New Evidence for the Breakup of Rodinia
}

\author{
Shengyuan Shu ${ }^{1,2}$, Xiaoyong Yang ${ }^{1,2, *}$, Lei Liu ${ }^{1, *}$, Wei Liu ${ }^{1,3}$, Jingya Cao ${ }^{1} \mathbb{C}$ and Ergen Gao ${ }^{4}$ \\ 1 CAS Key Laboratory of Crust-Mantle Materials and Environments, School of Earth and Space Sciences, \\ University of Science and Technology of China, Hefei 230026, China; syshu@mail.ustc.edu.cn (S.S.); \\ cdcgs_liuwei@163.com (W.L.); jingyacao@126.com (J.C.) \\ 2 State Key Laboratory of Continental Dynamics, Northwest University, Xi'an 710069, China \\ 3 Chengdu Center, China Geological Survey, Chengdu 610081, China \\ 4 College of Civil Engineering, Anhui Jianzhu University, Hefei 230601, China; grg@126.com \\ * Correspondence: xyyang@ustc.edu.cn (X.Y.); liu01@ustc.edu.cn (L.L.)
}

Received: 17 March 2018; Accepted: 21 May 2018; Published: 28 May 2018

\begin{abstract}
Neoproterozoic intraplate magmatic rocks are widespread in the Yangtze Block (YZB). The contrasting interpretations on their petrogenesis and tectonic evolution induce stimulating discussions on the coeval tectonic setting, including the two competing models of rift-related (R-model) and arc-related (A-model). Their main evidence is dominantly from felsic magmatic rocks. In contrast, the less evolved basic rocks are more suitable for tectonic setting discrimination. Here we study the Longtanqing basic intrusions (LTQ) that are exposed to the central part of the N-S trending Kangdian rift in the western YZB, by detailed geochemical and geochronological investigations. Zircon U-Pb dating of the two diabases from LTQ yield identical ages within error of $777 \pm 17 \mathrm{Ma}$ and $780 \pm 5.3 \mathrm{Ma}$, respectively. LTQ rocks are characterized by low $\mathrm{SiO}_{2}(49.83-50.71 \mathrm{wt} \%)$, high $\mathrm{MgO}$ (5.91-6.53 wt \%), and $\mathrm{Cr}$ (140-150 ppm) contents, supporting the significant mantle affinity. They also display dual geochemical characteristics, including a series of features of continental within-plate basalts (WPB, $\mathrm{Ti} / \mathrm{V}=37.3-47.5, \mathrm{Zr} / \mathrm{Y}=3.4-3.8, \mathrm{Ta} / \mathrm{Hf}=0.19-0.23$ ), and the typical signatures of island arc basalt (IAB), such as highly depleted in HFSE and HREE, and enriched in LREE and LILE. Most zircon $\varepsilon_{\mathrm{Hf}}(\mathrm{t})$ values are positive (1.6-9.4) while the corresponding Hf depleted mantle model ages $\left(\mathrm{T}_{\mathrm{DM} 1}\right)$ range from $1.0 \mathrm{Ga}$ to $1.3 \mathrm{Ga}$. In combination with the occurrence of inherited zircons (991-1190 Ma), it is suggested that their sources are dominantly derived from the lithospheric mantle that was reconstructed in the late Mesoproterozoic. Thus, LTQ is mainly formed by partial melting of the enriched lithospheric mantle, and subsequently assimilated by a juvenile crust during upwelling. The melt compositions are controlled by different degrees of the crystal fractionation of the dominant clinopyroxene and plagioclase with minor amphibole under high $f \mathrm{O}_{2}$ conditions. Combined with previous geochronological and geochemical data in the YZB, our new results support the theory that the R-model can be responsible for the petrogenesis of Neoproterozoic magmatic rocks in South China.
\end{abstract}

Keywords: Neoproterozoic magmatism; continental rifting; Rodinia breakup; Yangtze Block

\section{Introduction}

The Rodinia supercontinent is assembled along the Greenville Orogen during ca. 1.3 and 1.0 $\mathrm{Ga}$, and broken up during ca. $0.85-0.74 \mathrm{Ga}$. The breakup event is marked by the widespread continental rifts, anorogenic magmatism, and emplacement of mafic dyke swarms in cratons, like South China, Tarim, North American, India, South Africa, and Australia [1-14]. Numerous 
Grenvillian subduction-related and Neoproterozoic (0.85-0.74 Ga) rift-related magmatic rocks have been recognized on the South China Block (SCB), in particular at the margin of the Yangtze Block (YZB) (Figure 1), which witnessed an assembling configuration and breakup of the Rodinia supercontinent. Therefore, the tectonic affinity of Neoproterozoic magmatic rocks in the YZB is important for understanding the role and location of the block during the time of the reconstruction and the supercontinent breakup.

Neoproterozoic magmatic rocks are widespread in the YZB, including dominantly felsic igneous rocks and relatively considerable basic rocks (Table S1). However, the petrogenesis and tectonic affinities of these magmatic rocks are still controversial [15-18]. Two major but conflicting tectonic models, called rift-related (R-model) and arc-related (A-model), have been proposed. The R-model suggests that the magmatism is produced in the Neoproterozoic mantle plume related rift setting [4,8,19-27], which is based on data about the geochemistry, geochronology, and paleomagnetism $[3,7,20]$, as well as other aspects such as basin analysis and petrologic data $[4,9,28-30]$. The A-model argues that the arc magmatism around the margins of the YZB is responsible for the Neoproterozoic magmatic rocks [31-37], in terms of (1) arc signatures in geochemical compositions (e.g., Nb, Ta and Ti depletion); and (2) the presence of arc assemblages showing identical Neoproterozoic ages $[17,18,38]$. The competing tectonic models have different implications, such as the relative location of SCB in Rodinia: whether SCB was the link between North America and Australia-East Antarctica, which was the core of the Rodinia [4,39], or located on the periphery of Rodinia [31,32]. Hence, it requires further studies on tectonic affinity in order to understand the geodynamics of SCB. Previous studies have demonstrated that the less evolved basic rocks are better for tectonic affinity discrimination than those of mature felsic to intermediate rocks [40]. Unfortunately, the samples for supporting both models are mainly from felsic rocks and intermediate rocks; few basic rocks are involved as a result of their rare occurrences in the SCB.

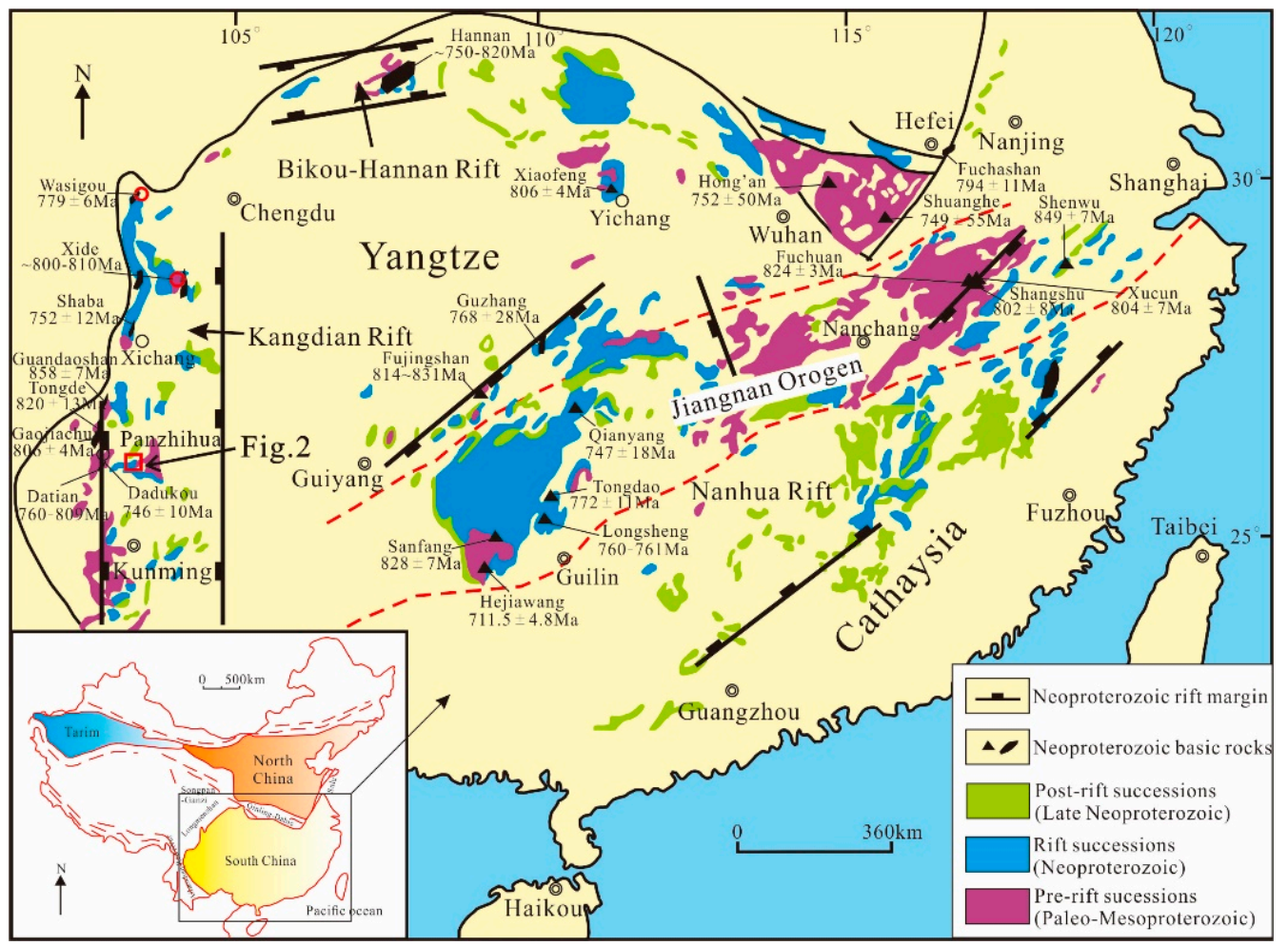

Figure 1. Schematic map of Precambrian South China Block (SCB) emphasizing the three Neoproterozoic rift basins and distribution of Neoproterozoic basic rocks (after [3,28,41,42]). The inset is a tectonic sketch of China showing the three Precambrian blocks (after [43]). Detailed data of the basic rocks in the Yangtze Block (YZB) can see in Table S1. 
The basic intrusions can play an important role on the study of the mechanism and processes of the supercontinent breakup [44]. Recently, some Neoproterozoic basic intrusions have been recognized in the SCB (Table S1), in particular in the western and northern YZB, e.g., Wasigou gabbro intrusions [22], Xide diabase dykes [42], Hannan, and Micangshan mafic intrusions [45,46] — they all have already been considered as generating within an intraplate extension or subduction environment. In this study, we investigate the newly found Longtanqing basic intrusions (LTQ) exposed to the central part of the $\mathrm{N}-\mathrm{S}$ trending Kangdian rift, and obtain a series of data, consisting of the $\mathrm{U}-\mathrm{Pb}$ and $\mathrm{Lu}-\mathrm{Hf}$ isotopic results of zircons, and whole-rock geochemical compositions. These new data, in combining with data from the literature, provide not only further constraints on the petrogenesis and tectonic setting of the Neoproterozoic rocks, but also insights into the response of the supercontinent breakup in the YZB.

\section{Geological Background and Sampling}

South China comprises the northwest of the YZB and southeast of the Cathaysia Block (CYB) (Figure 1). The amalgamation of the YZB and CYB probably occurred at $\sim 0.86 \mathrm{Ga}$ [47-49]. The YZB is bounded by the CYB to the southeast, the Qinling-Dabie orogenic belt to the north, the Tibetan Plateau to the west, and the Indochina Block to the southwest (Figure 1). There is a Precambrian basement overlain by the Sinian to Cenozoic cover sequences [50]. The Archean-Paleoproterozoic basement is sporadically exposed in the western and northern parts of the YZB [43,51-53]. The Kongling Complex, the only known Archean basement, lies in the northern YZB with zircon U-Pb ages of 2.95-2.90 Ga, consisting of tonalite-trondhjemite-granodiorite (TTG) gneisses, amphibolites, and meta-sedimentary rocks [54]. However, the Neoproterozoic magmatism is widely distributed in the three main rift basins on the margin of YZB: (1) the N-S trending Kangdian rift to the western margin; (2) the nearly E-W trending Bikou-Hannan Rift to the northwestern; and (3) the major NE-SW trending Nanhua Rift along the Jiangnan orogenic belt (Figure 1; [3,7,19,25,26,28,29,41,55]). These rift successions consist of marine silicic-volcaniclastic rocks interbedded with volcanics, mostly consisting of tuffs $[6,28,29,41,55,56]$.

In the western YZB, Proterozoic rift volcanic-sedimentary sequences occur in the Kangdian rift, including the late Paleo-Mesoproterozoic Dongchuan, Hekou, and Dahongshan Groups, and the Neoproterozoic Huili and Kunyang Groups [51,52,57,58], which are along the Luzhijiang fault and a series of related NNE-trending faults. Among them, the Huili Group is mainly distributed in the Tong'an area, Huili County, southwestern China (Figure 2), and is a more than $10 \mathrm{~km}$-thick sequence of meta-clastic and meta-carbonate rocks interbedded with volcanic rocks, which includes the Yinmin, Luoxue, Heishan, Qinglongshan, Limahe, Fenshan, and Tianbaoshan Formations, from the base upward. A meta-volcanic sample from the Tianbaoshan Formation gave a SHRIMP zircon U-Pb age of $1028 \pm 9 \mathrm{Ma}$ [57], which is consistent with those ages of the Upper Kunyang, Dengxiangying and Ebian Groups [57-59]. The Huili Group is unconformably overlain by the Sinian Dengying Formation and younger strata, and intruded by numerous Meso- to Neoproterozoic magmatic intrusions, including LTQ (Figure 2). And these intrusions have closely spatial and temporal relationship to the iron oxide (copper) deposits in this region, especially for basic magmatism [60].

The LTQ crop out in the southern part of the Tong'an region (Figure 2). These intrusions, dominantly composed of basic rock bodies, occur as dykes and irregular intrusions that intrude the dolomite or shales of the Mesoproterozoic Heishan Formation, the Huili Group (Figures 2 and 3a). These intrusions are up to $3 \mathrm{~km}$ long and commonly 400-3000 m wide, striking NNW along with the fault. The samples were collected from the Longtanqing deposit (Figures $2 b$ and $3 a$ ), which consist of fine- to medium-grained diabase (Figure 3b). The rock is mainly composed of sub-anhedral crystals of plagioclase $(60-70 \%)$, hornblende ( 15-25\%), clinopyroxene $(5 \sim 10 \%)$ and biotite $(\sim 10 \%)$, with minor apatite, opaque minerals (iron oxide minerals) (Figure $3 c-f$ ). Most of the intrusions may experience variable degrees of alteration, resulting in the albitization of some plagioclases, hornblende altered to chlorite, and some clinopyroxenes surfaces also had the phenomenon of iron precipitation (Figure $3 \mathrm{e}, \mathrm{f}$ ). In this research, we collected eight fresh samples to analyze the whole-rock geochemistry and two zircon samples for $\mathrm{U}-\mathrm{Pb}$ dating and $\mathrm{Hf}$ isotopic analysis. 


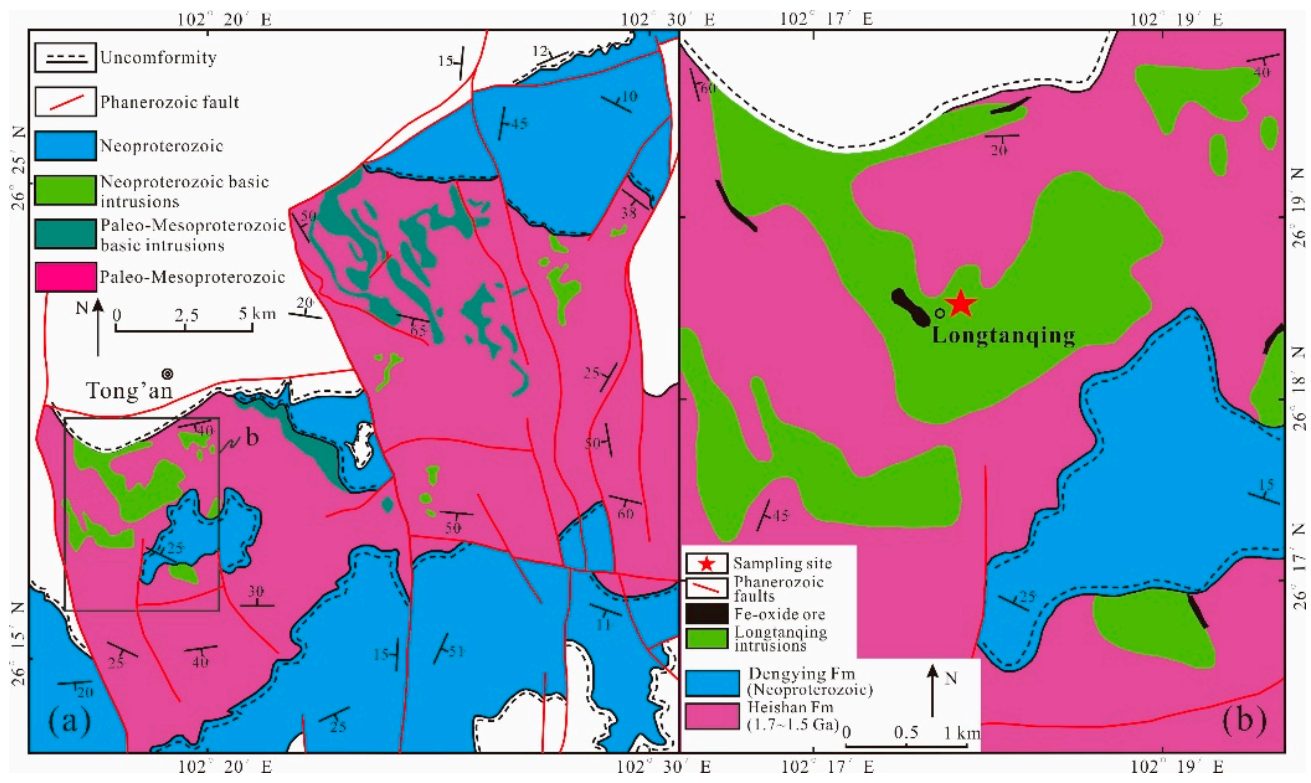

Figure 2. (a) Simplified geological map of Mesoproterozoic to Neoproterozoic rocks in the Tong'an region; (b) Geological map of the LTQ and sample locations.

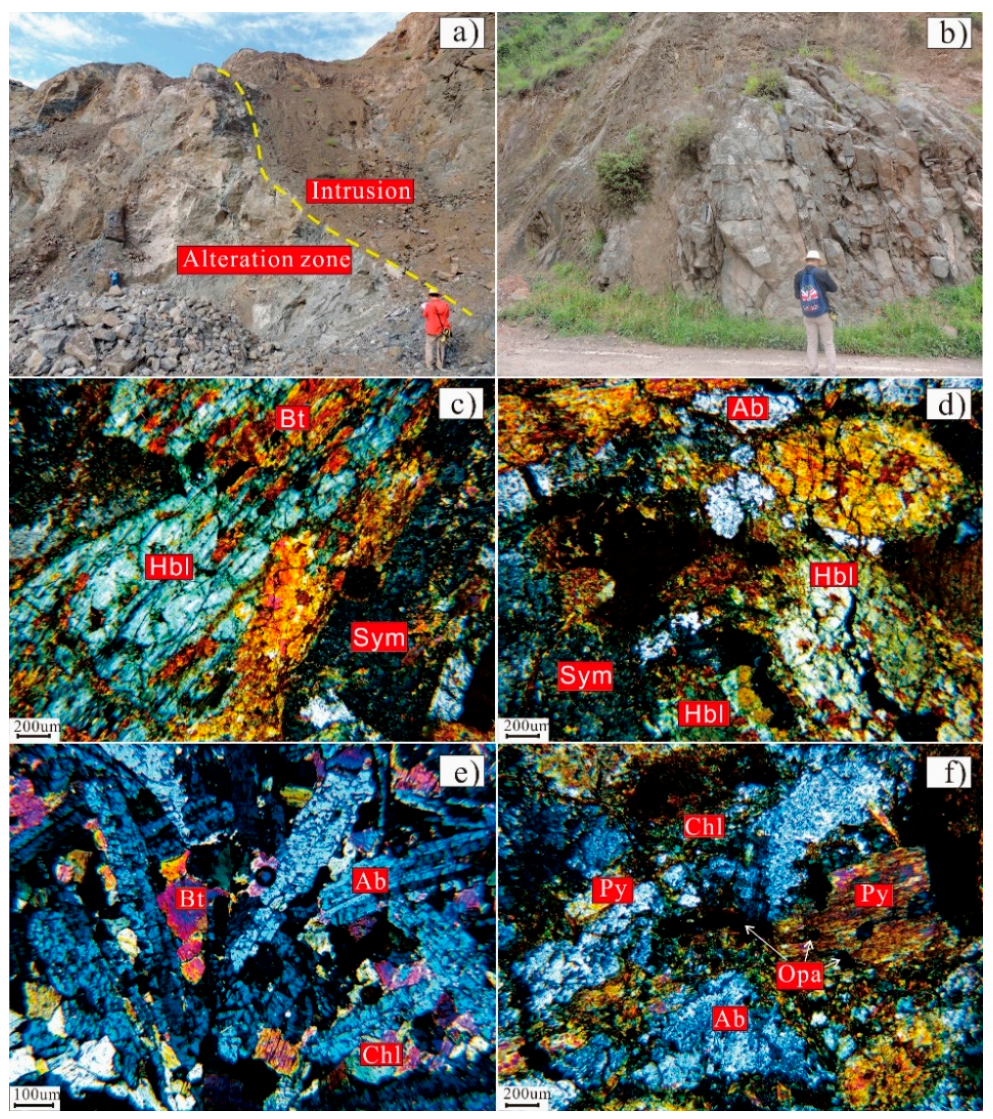

Figure 3. Outcrop photographs and photomicrographs of the basic rocks of the LTQ. (a) Field photos show the intrusion intrudes the dolomite of the Heishan Fm; (b) Field photos of the LTQ; (c,d) Microphotographs of the rock-forming minerals; (e,f) Microphotographs of minerals with hydrothermal alteration. $\mathrm{Ab}=$ Albite, $\mathrm{Bt}=$ Biolite, $\mathrm{Chl}=$ Chlorite, $\mathrm{Hbl}=$ Hornblende, Opa = Magnetite $/$ Ilmenite, Py = Pyroxene, Sym = Symplectite . 


\section{Analytical Methods}

\subsection{Major and Trace Element Analyses}

The freshness of the samples analyzed during this study was ensured by sampling the cores of dikes and intrusions rather than the weathered exterior. Whole-rock major and trace elements were analyzed at the ALS Geochemistry Laboratory in Guangzhou. First, the steel jaw crusher was used to crush the fresh samples, and then the small blocks were powdered in an agate mill until the grain size $<200$ mesh. For major oxides concentrations, these were carried out on a standard wavelength dispersive X-ray fluorescence spectrometry (XRF). The determination of loss on ignition (LOI) was conducted after igniting the sample powders at $1000{ }^{\circ} \mathrm{C}$ for $1 \mathrm{~h}$ by gravimetric methods. Then, whole-rock powder $(0.5 \mathrm{~g})$ was added to $0.9 \mathrm{~g}$ of $\mathrm{Li}_{2} \mathrm{~B}_{4} \mathrm{O}_{7}-\mathrm{LiBO}_{2}$, mixed well, fused in an auto-fluxer between $1050{ }^{\circ} \mathrm{C}$ and $1100{ }^{\circ} \mathrm{C}$, and cooled to form a flat molten glass disk. This disk was analyzed by wavelength-dispersive XRF using an AXIOS Minerals spectrometer. The long term analytical uncertainties are generally within $0.1-1 \%$ (RSD) for major elements based on the duplicate measurements of silicate standards (BHVO- 1 and AGV-1 from USGS). For trace and REE concentrations, a solution of the powdered samples was kept for two days in sealed beakers for digestion using a mixture of $\mathrm{HF}$ and $\mathrm{HNO}_{3}$ acid in a Teflon screw-cap bomb. Then, this solution was run through an Elan DRC-II instrument (Element, Finnigan MAT) that used inductively coupled plasma mass spectrometry (ICP-MS). The uncertainties of the ICP-MS analyses are estimated to be better than $5 \%$. Detailed analytical methods were described by Liu [61].

\subsection{LA-ICPMS Zircon U-Pb Dating and Trace Element Analyses}

Zircon grains were separated from samples 16LTQ-1 and 16LTQ-2 using magnetic and heavy liquid separation techniques, mounted in epoxy resin and polished to about half their thickness and then photographed in reflected and transmitted light. The structures of the zircon grains were imaged by cathodoluminescence (CL) techniques at the Analytical Center of the University of Science and Technology of China, Hefei (USTC). CL imaging was used to investigate crystal morphologies and internal structure and to select analytical spots. Zircon grains were analyzed for $\mathrm{U}-\mathrm{Pb}$ dating and trace elements using the Laser Ablation Inductively-Coupled Plasma Mass Spectrometry (LA-ICPMS) method at the in situ Mineral Geochemistry Lab, Ore Deposit and Exploration Centre (ODEC), Hefei University of Technology, China. The analyses were carried out on an Agilent 7900 Quadrupole ICP-MS coupled to a Photon Machine Analyte HE 193-nm ArF Excimer laser ablation system. The ablated spot diameter of the ion beam was set at $25 \mathrm{um}$. Argon was used as the make-up gas and Helium was applied as carrier gas. NIST SRM 610 glass was used as the external calibration standard and ${ }^{29} \mathrm{Si}$ was used as the internal standard to normalize the trace element. Zircon 91500 was used as the standard for U-Pb dating with a recommended ${ }^{206} \mathrm{~Pb} /{ }^{238} \mathrm{U}$ age of $1065.4 \pm 0.6 \mathrm{Ma}$ [62]. Quantitative calibration for the zircon U-Pb dating and trace elements were carried out on ICPMSDataCal 10.7 [63,64]. Data reduction was carried out using the isoplot v3.0 program [65].

\subsection{Zircon Lu-Hf Isotope Analyses}

After the zircon $\mathrm{U}-\mathrm{Pb}$ isotope measurement, the in situ Lu-Hf isotopic analysis was conducted at the laboratory of the Tianjin Institute of Geology and Mineral Resource, Chinese Academy of Geological Sciences. The Lu-Hf isotopes were measured by a Thermo Finnigan Neptune (Plus) MC-ICPMS, equipped with a 193-nm ArF-excimer laser ablation system. The instrumental parameter and data acquisition was followed according to the method described by Wu et al. [66] and Geng et al. [67]. The laser beam diameter was $50 \mathrm{um}$, with a $10 \mathrm{~Hz}$ repetition rate and $15 \mathrm{~J} / \mathrm{cm}^{2}$ energy density. Helium was used as the carrier gas to transport the laser eroded matter in Neptune (MC-ICP-MS). Zircon standard GJ-1 was used as the external calibration to evaluate the reliability of the analytical data, the recommended ${ }^{176} \mathrm{Hf} /{ }^{177} \mathrm{Hf}$ ratio of $0.282006 \pm 24\left(2 \sigma\right.$, [67]). Isobaric interferences of ${ }^{176} \mathrm{Lu}$ and ${ }^{176} \mathrm{Yb}$

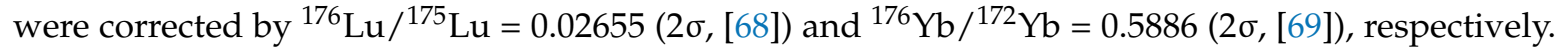


Meanwhile, in order to calculate the mean $\beta_{\mathrm{Yb}}$ value, a mean ${ }^{173} \mathrm{Yb} /{ }^{171} \mathrm{Yb}$ ratio was used, and then the ${ }^{176} \mathrm{Yb}$ signal intensity was calculated with the help of the ${ }^{173} \mathrm{Yb}$ signal intensity and the mean $\beta_{\mathrm{Yb}}$ value [70]. Time-drift correction and external calibration were done using zircon standard 91500. In this research, we adopted the decay constant for ${ }^{176} \mathrm{Lu}$ of $1.865 \times 10^{-11} \mathrm{a}^{-1}$ [71], the present-day chondritic ratios of ${ }^{176} \mathrm{Hf} /{ }^{177} \mathrm{Hf}=0.282772$ and ${ }^{176} \mathrm{Lu} /{ }^{177} \mathrm{Hf}=0.0332$ [72], the present-day depleted mantle value of ${ }^{176} \mathrm{Hf} /{ }^{177} \mathrm{Hf}=0.28325$ [73], and ${ }^{176} \mathrm{Lu} /{ }^{177} \mathrm{Hf}=0.0384$ [74] to calculate initial ${ }^{176} \mathrm{Hf} /{ }^{177} \mathrm{Hf}$ ratios, $\varepsilon_{\mathrm{Hf}}(\mathrm{t})$ values, and single-stage model ages $\left(\mathrm{T}_{\mathrm{DM} 1}\right)$ when their $\varepsilon_{\mathrm{Hf}}(\mathrm{t})$ values were positive.

\section{Results}

\subsection{Zircon LA-ICPMS U-Pb Dating and Trace Elements}

The results of LA-ICPMS U-Pb isotopic analyses are listed in the supplementary data Table S2, and the data for all analyses are plotted on concordia diagrams within the analytical errors (Figure 4a,b). The representative zircon grains CL images are displayed in Figure 4c. The zircons are quite small (40-100 um), generally simple prismatic, colorless, transparent, and euhedral, with length to width ratios between 1:1 and 2:1. Most of them show obvious oscillatory zoning with different luminescence (Figure $4 \mathrm{c}$ ), with $\mathrm{Th} / \mathrm{U}$ ratios ranging from 0.42 to 1.03 , almost more than 0.4 , indicating a magmatic origin $[75,76]$. Weighted mean ${ }^{206} \mathrm{~Pb} /{ }^{238} \mathrm{U}$ dates are used to access their age, and inherited zircons and detrital zircon with variably older ${ }^{206} \mathrm{~Pb} /{ }^{238} \mathrm{U}$ ages are not used when calculating crystallization ages. The data with concordance of less than $94 \%$ were excluded.
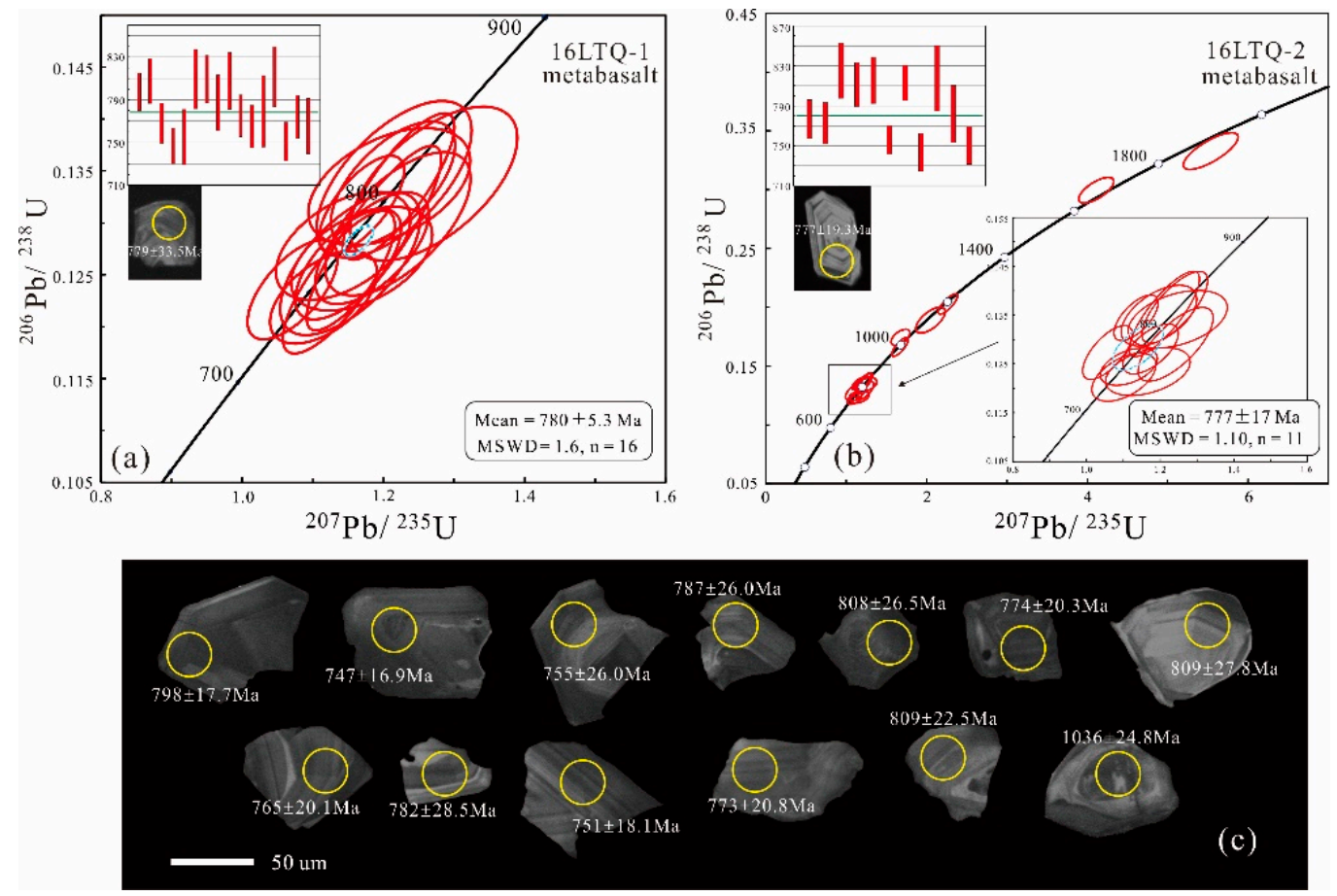

Figure 4. Zircon LA-ICPMS U-Pb concordia diagrams $(\mathbf{a}, \mathbf{b})$ and representative cathodoluminescence (CL) images (c) of laser ablated zircon crystals from the LTQ.

Sixteen analyses were conducted on 16 zircons from sample 16LTQ-1, uranium and thorium concentrations are variable, ranging from 51.7 to $342 \mathrm{ppm}$, and from 29.4 to 319 ppm, respectively. The Th/U ratios of the zircons range from 0.54 to 0.97 . The zircons of sample 16LTQ-1 form a tight cluster on concordia and yield a weighted mean ${ }^{206} \mathrm{~Pb} /{ }^{238} \mathrm{U}$ age of $780 \pm 5.3 \mathrm{Ma}(n=16, \mathrm{MSWD}=1.6$, $2 \sigma$ ) (Figure 4a), which is regarded as the crystallization of the sample. Seventeen zircons were analyzed from sample 16LTQ-2, the U and Th concentrations are ranging from 48 to 329 ppm, and from 38.9 
to $339 \mathrm{ppm}$, respectively. The Th/U ratios of most of the zircons range from 0.42 to 1.03 , except two zircons that have low $\mathrm{U}$, Th concentrations and $\mathrm{Th} / \mathrm{U}$ ratios, on which the inclusions can be seen under the CL images. Most zircon U-Pb analyses from 16LTQ-2 yield concordant U-Pb ages with weighted mean ${ }^{206} \mathrm{~Pb} /{ }^{238} \mathrm{U}$ age of $777 \pm 17 \mathrm{Ma}(n=11, \mathrm{MSWD}=1.1,2 \sigma)$ (Figure $\left.4 \mathrm{~b}\right)$. This age is interpreted as the crystallization age of the sample 16LTQ-2. Some zircons have distinctive cores (Figure 4c), which may be inherited from previous events, all these inherited cores must also be of magmatic origin given their oscillatory zonings; four concordant analyses of inherited cores yielded ${ }^{206} \mathrm{~Pb} /{ }^{238} \mathrm{U}$ ages of 991-1190 Ma (Figure 4). In addition, there are two captured zircons showing a relatively older age of Paleoproterozoic (1689 and $1852 \mathrm{Ma}$ ), which are consistent with the ancient basement (Dongchuan Group) of this area.

The results of the trace elements in zircons from the LTQ analyzed by LA-ICPMS are listed in the supplementary data Table S3. Except for one spot analysis (16LTQ-1-5), which has high concentrations of $\mathrm{P}$ and Ti (Table S3), there may be ablate apatite inclusion. The chondrite-normalized REE diagrams of the two samples both show enrichments in HREE, depletions in LREE, negative Eu anomalies and positive Ce anomalies in most zircons (Figure $5 a, b$ ), which are different from the zircons of metamorphic origin [77] but consistent with their magmatic origin [78,79].
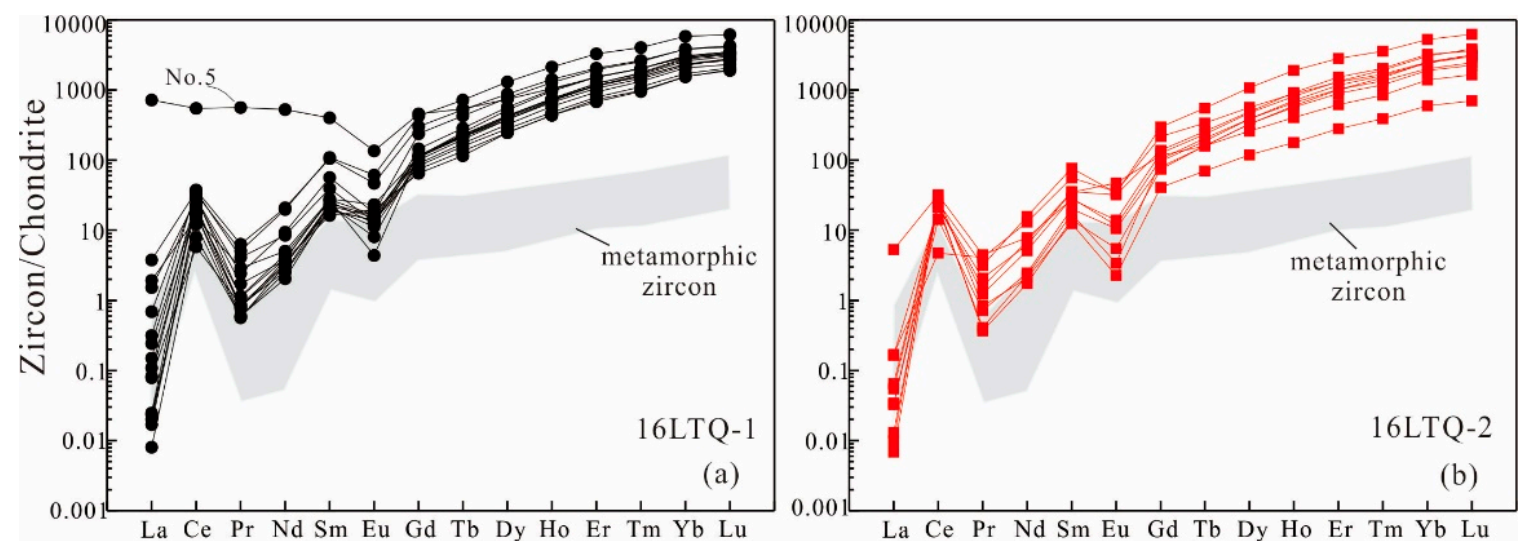

Figure 5. Zircon chondrite-normalized REE diagrams of the two samples (a) 16LTQ-1 and (b) 16LTQ-2. Chondritic values are from [80]. The detailed data of metamorphic zircons come from [77].

\subsection{Geochemical Characteristics}

Whole Rock Major and Trace Elements

The samples of the LTQ range from $49.83 \%$ to $50.71 \% \mathrm{SiO}_{2}, 3.64 \%$ to $4.49 \% \mathrm{~K}_{2} \mathrm{O}, 5.84 \%$ to $6.26 \%$ $\mathrm{MgO}, 16.58 \%$ to $17.10 \% \mathrm{Al}_{2} \mathrm{O}_{3}, 10.07 \%$ to $10.81 \% \mathrm{TFe}_{2} \mathrm{O}_{3}$ (abbreviation of total $\mathrm{Fe}_{2} \mathrm{O}_{3}$ ), and $1.40 \%$ to $2.29 \% \mathrm{CaO}$, which expresses low $\mathrm{SiO}_{2}$, and high $\mathrm{K}_{2} \mathrm{O}, \mathrm{Al}_{2} \mathrm{O}_{3}, \mathrm{MgO}, \mathrm{TFe}_{2} \mathrm{O}_{3}$ contents (Table S4). Thus, the samples are characterized by low $\mathrm{SiO}_{2}$ contents and high magnesium number (Mg\#, 52.2 to 54.5), which represent the typical basic rocks. In addition, the high concentrations of $\mathrm{Na}_{2} \mathrm{O}(5.39 \%$ to $5.77 \%)$ and LOI $(2.21 \%$ to $2.96 \%)$ are also consistent with the widespread sodic alteration. On the Harker diagrams (Figure 6), $\mathrm{Fe}_{2} \mathrm{O}_{3}, \mathrm{Al}_{2} \mathrm{O}_{3}$, and $\mathrm{K}_{2} \mathrm{O}$ contents decrease, whereas $\mathrm{SiO}_{2}, \mathrm{TiO}_{2}$ and $\mathrm{P}_{2} \mathrm{O}_{5}$ contents increase with decreasing $\mathrm{MgO}$ contents, suggesting the crystallization of the pyroxene or amphibole. In the rock classification diagram, the samples belong to tholeiitic basalts (Figure 7). 

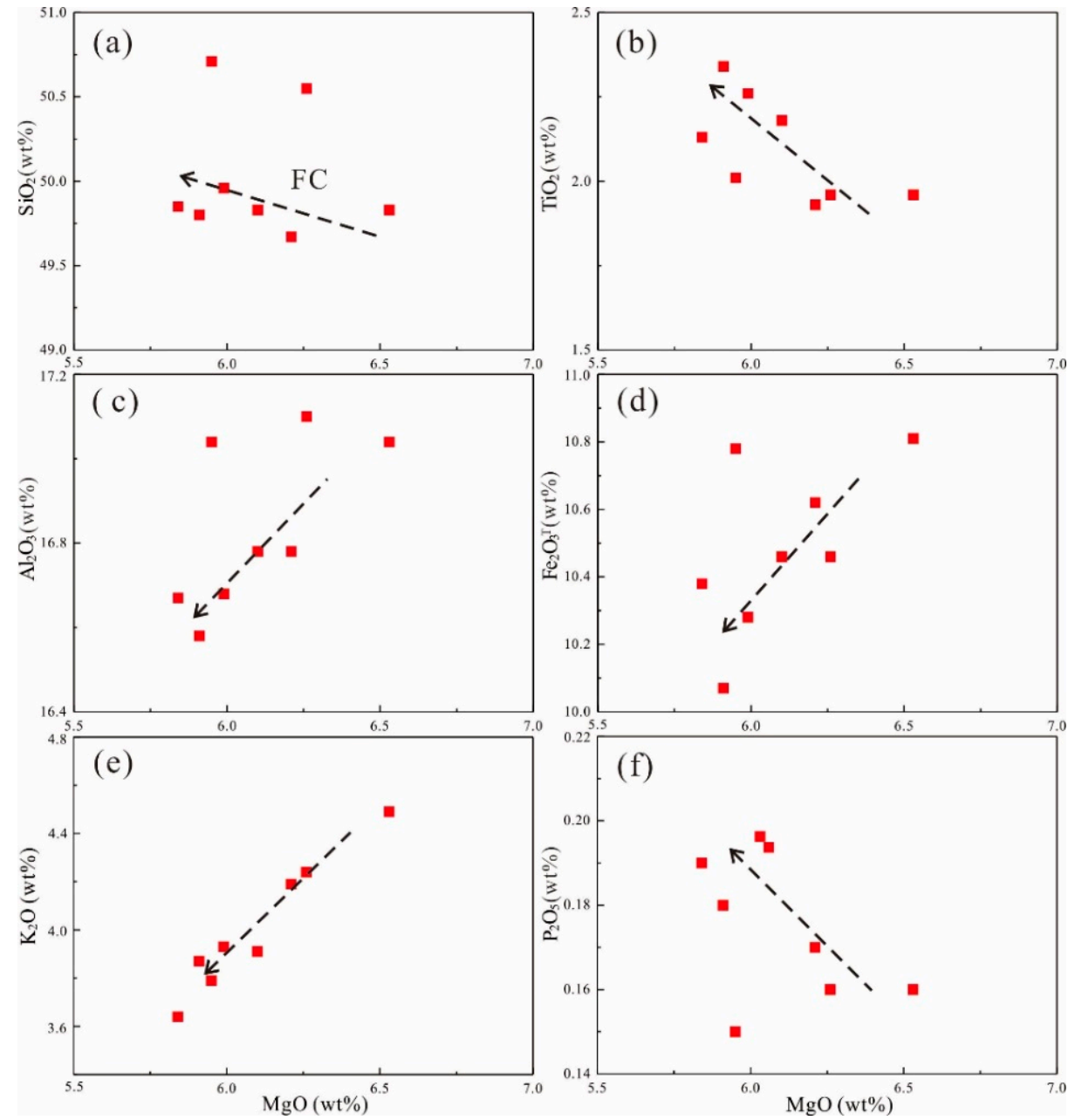

Figure 6. Harker diagrams showing the major element variations of the LTQ. FC-fractional crystallization. $\mathrm{Fe}_{2} \mathrm{O}_{3}{ }^{\mathrm{T}}$ (d); $\mathrm{Al}_{2} \mathrm{O}_{3}$ (c); and $\mathrm{K}_{2} \mathrm{O}$ (e) contents decrease, whereas $\mathrm{SiO}_{2}(\mathbf{a}) ; \mathrm{TiO}_{2}(\mathbf{b})$ and $\mathrm{P}_{2} \mathrm{O}_{5}$ (f) contents increase with decreasing $\mathrm{MgO}$ contents.
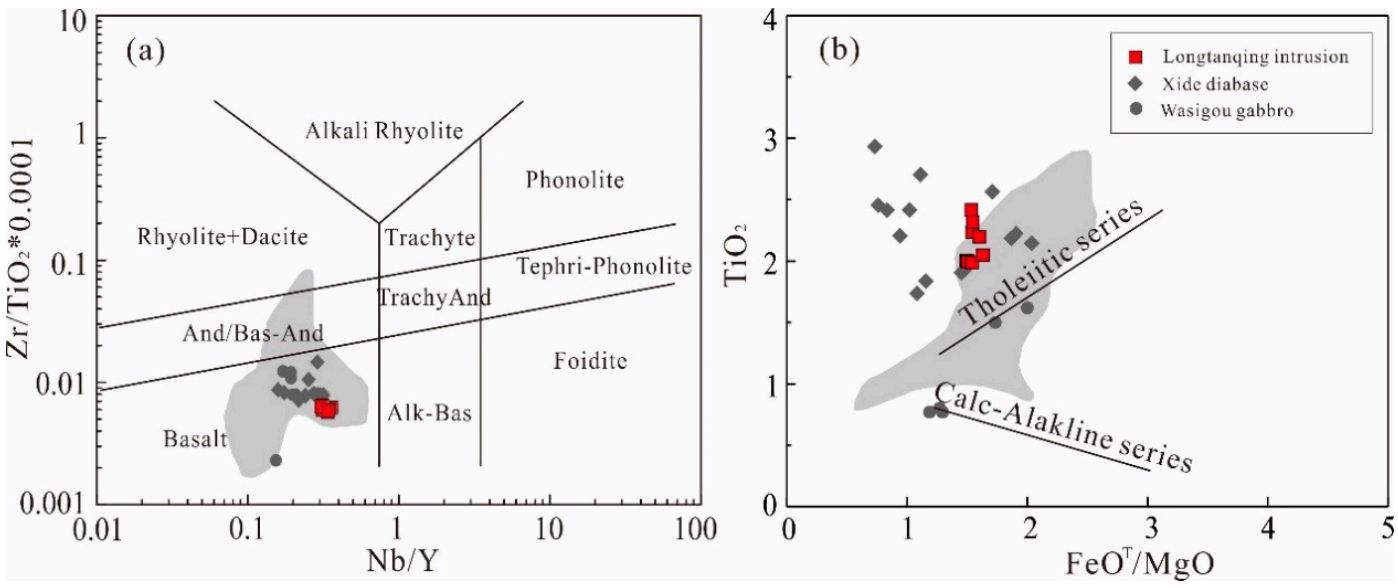

Figure 7. Rock classification diagrams for the samples. (a) $\mathrm{Nb} / \mathrm{Y}-\mathrm{Zr} / \mathrm{TiO}_{2}{ }^{*} 0.0001$ diagram distinguishing subalkaline and alkaline rocks [81]; (b) $\mathrm{FeO}_{\mathrm{T}} / \mathrm{MgO}-\mathrm{TiO}_{2}$ diagram distinguishing tholeiitic and calc-alkaline series [82]. Data for Xide diabase dykes and Wasigou gabbros of western YZB are from [42] and [22], respectively. The shaded areas outline the ranges of compositions for basic-ultrabasic rocks from the Hannan Massif of northwestern YZB with data source from [45]. 
As shown in the chondrite-normalized REE pattern diagrams (Figure 8a), the LTQ rocks have similar REE distribution curves, and they also have relatively high REE contents ( 2 REE = 99.6-115.6 ppm) that relate them to island arc basalts (IABs). Most of these samples are enriched in LREE $\left(\mathrm{LREE}=76.1-92.0 \mathrm{ppm}, \mathrm{LREE} / \mathrm{HREE}=3.2-4.1, \mathrm{La}_{\mathrm{N}} / \mathrm{Sm}_{\mathrm{N}}=1.9-2.1, \mathrm{La}_{\mathrm{N}} / \mathrm{Yb}_{\mathrm{N}}=3.1-4.3\right)$, and display slight right-inclined REE distribution patterns and insignificant $\mathrm{Eu}$ anomalies $\left(\mathrm{Eu} / \mathrm{Eu}_{\mathrm{N}}{ }^{*}=0.90-1.04\right.$, $\left.\mathrm{Eu} / \mathrm{Eu}_{\mathrm{N}}{ }^{*}=\mathrm{Eu}_{\mathrm{N}} /\left[\left(\mathrm{Sm}_{\mathrm{N}}\right) \times\left(\mathrm{Gd}_{\mathrm{N}}\right)\right]^{0.5}\right)$. Basically, all samples fall in the field between oceanic island basalt (OIB) and island arc basalt (IAB), and show slightly fractionated inner HREE (Figure 8a). These patterns are completely different from the typical OIB, which is intensively differentiated in LREE and HREE, but is similar to the island arc basalt (IAB). On the primitive mantle-normalized incompatible element diagrams (Figure 8b), the LTQ rocks also show broadly similar shapes, which are obviously enriched in $\mathrm{Rb}, \mathrm{Ba}, \mathrm{K}, \mathrm{U}$, and depleted in $\mathrm{Nb}, \mathrm{Ta}$, Ti. These patterns are approximatively consistent with typical IAB, which show the same $\mathrm{Nb}$-Ta anomalies and slight Ti negative anomalies (Figure $8 \mathrm{~b}$ ).
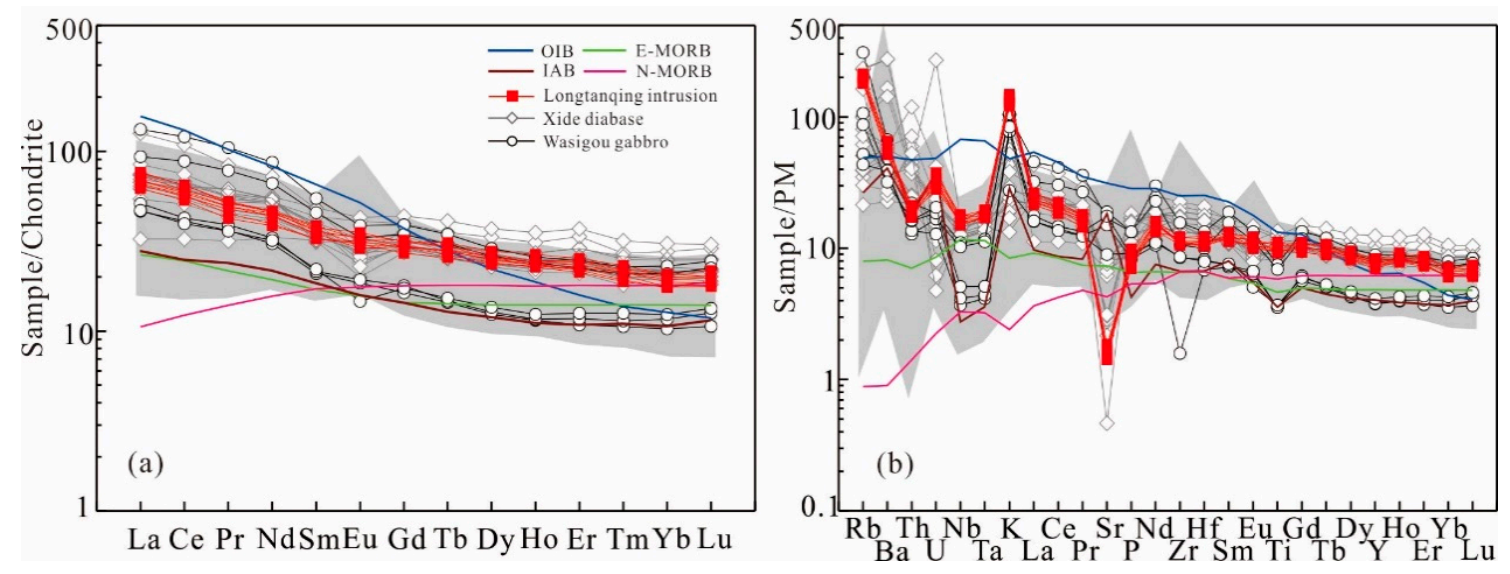

Figure 8. Chondrite-normalized REE pattern (a) and primitive mantle-normalized incompatible trace element spider diagrams (b) for the LTQ samples, Xide diabase dykes [42], and Wasigou gabbros [22], western YZB. The data for chondrite, primitive mantle values are from [80]. The average compositions of enriched mid-ocean ridge basalt (E-MORB), normal mid-ocean ridge basalt (N-MORB), ocean island basalt (OIB), and island arc basalt (IAB) are from [80] and [83]. The shaded areas outline the ranges of compositions for basic-ultrabasic rocks from the Hannan Massif of northwestern YZB with data source from [45].

The geochemical characteristics of the LTQ are comparable with other contemporary basic rocks in the western and northern YZB, such as Wasigou gabbros (779 $\pm 6 \mathrm{Ma}$ ) [22], Xide diabase dykes ( 800-810 Ma) [42], and most Hannan basic-ultrabasic intrusions [45] (Figures 7 and 8).

\subsection{Zircon Lu-Hf Isotopes}

The in situ zircon Lu-Hf isotopic composition analyses come from the two samples of 16LTQ-1 and 16LTQ-2, and the results are given in supplementary data Table S5. Sixteen Lu-Hf spots are performed from sample 16LTQ-1, the results show variable ${ }^{176} \mathrm{Lu} /{ }^{177} \mathrm{Hf}$ ratios of 0.0006 to 0.0024 , but present-day ${ }^{176} \mathrm{Hf} /{ }^{177} \mathrm{Hf}$ ratios of 0.282287 to 0.282569 are similar. The calculated initial ${ }^{176} \mathrm{Hf} /{ }^{177} \mathrm{Hf}$ ratios vary from 0.282268 to 0.282552 with a mean of 0.282394 , the $\varepsilon_{\mathrm{Hf}}(\mathrm{t})$ values $(\mathrm{t}=780 \mathrm{Ma})$, which represent the $\varepsilon_{\mathrm{Hf}}$ values of parental magma when the zircons crystallized. With the exception of one point, 16LTQ-1-1 $\left(\varepsilon_{\mathrm{Hf}}(\mathrm{t})=-0.6\right)$, all zircon $\varepsilon_{\mathrm{Hf}}(\mathrm{t})$ values have a positive variable range from 1.6 to 9.4 with a mean of 4.2. Young single-stage model ages $\left(\mathrm{T}_{\mathrm{DM} 1}\right)$ range from 972 to $1285 \mathrm{Ma}$ (Figure $9 \mathrm{a}$ and Table S5). Nine zircons from sample 16LTQ-2 are analyzed for Lu-Hf isotopes; the results show variable ${ }^{176} \mathrm{Lu} /{ }^{177} \mathrm{Hf}$ ratios of 0.0006 to 0.0022 and present-day ${ }^{176} \mathrm{Hf} /{ }^{177} \mathrm{Hf}$ ratios range from 0.282360 to 0.282477 . The calculated initial ${ }^{176} \mathrm{Hf} /{ }^{177} \mathrm{Hf}$ ratios range from 0.282341 to 0.282457 , with an average of 0.282380 . The $\varepsilon_{\mathrm{Hf}}(\mathrm{t})$ values $(\mathrm{t}=777 \mathrm{Ma})$ vary from 1.9 to 6.0 with an average of 3.3 . The model $\mathrm{T}_{\mathrm{DM} 1}$ 
ages range from 1107 to $1271 \mathrm{Ma}$ (Figure $9 \mathrm{a}$ and Table S5). Zircon Hf model ages $\left(\mathrm{T}_{\mathrm{DM} 1}\right)$ of the two samples show a defining peak at $1.24 \mathrm{Ga}$ (Figure 9b). As shown in Figure 9, the samples all have the positive $\varepsilon_{\mathrm{Hf}}(\mathrm{t})$ values that are below the evolution line of the deplete-mantle, which suggest that the initial magmas might be derived from the melting of the mantle [84]. Meanwhile, the ages of $\mathrm{T}_{\mathrm{DM} 1}$ are only approximately $0.2-0.5 \mathrm{Ga}$ higher than the zircon $\mathrm{U}-\mathrm{Pb}$ ages of the samples (Table S5), suggesting the juvenile magmas may be partially melted directly from the depleted mantle and have assimilated minor crust $[84,85]$.
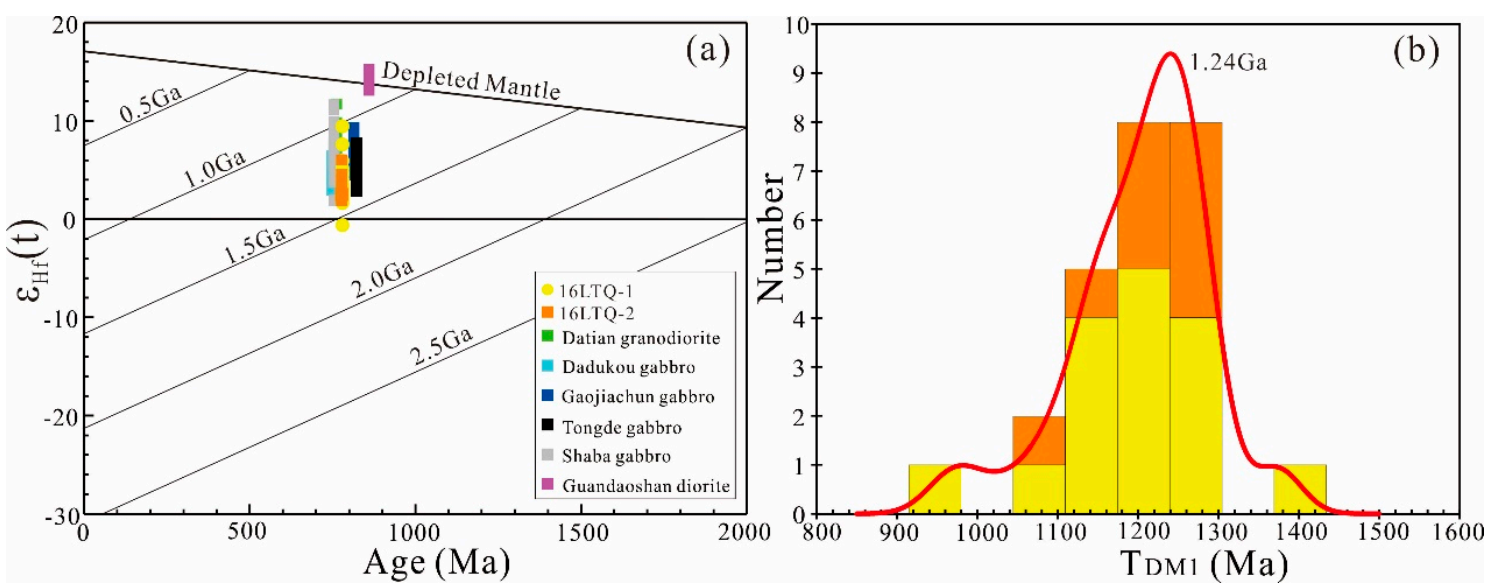

Figure 9. (a) Zircon Hf-isotope compositions diagram of LTQ (16LTQ-1, 16LTQ-2) and other Neoproterozoic intrusions in the western margin of YZB. Data of other intrusions are from [3,8,31,33-35,86]; (b) Histogram of model Hf ages $\left(\mathrm{T}_{\mathrm{DM} 1}\right)$ for the LTQ in the western YZB.

\section{Discussion}

\subsection{Age of the $L T Q$ and Regional Synchronous Magmatism}

There are many Neoproterozoic basic rocks that have been discovered in the YZB (Table S1; [3,4]), but the limited studies of geochemistry and geochronology have been used for the LTQ in the Tong'an area, Huili County, western YZB. The LTQ intruded into the Huili Group, was previously considered to be formed during the Permian like Emeishan basalt (the geological maps in scale of 1:200,000) or Mesoproterozoic Era [87] with the absence of a certain dating. Therefore, we dated two diabase samples from the LTQ to constrain its age. It is generally accepted that the closed system of Pb isotopes in zircon may be destroyed by later strong hydrothermal alteration, resulting in the loss of radiogenic $\mathrm{Pb}$, which eventually leads the calculated age to be lower than the actual age [88]. In our studies, most zircons are characterized by obvious oscillatory zonings, high $\mathrm{Th} / \mathrm{U}$ ratios $(>0.4)$, which are identified as magmatic zircons (Figures 4 and 5; Tables S2 and S3). The two ages from zircon U-Pb dating were fairly consistent with each other within error; they yielded the weighted mean ages of $780 \pm 5.3 \mathrm{Ma}$ and $777 \pm 17 \mathrm{Ma}$, respectively (Figure 4), and were interpreted as the best estimate of crystallization age and indicated that the emplacement age of the LTQ is ca. $780 \mathrm{Ma}$.

Various magmatic activities are broadly coeval with the LTQ in the YZB [3,17], especially on the western margin. For example, the $779 \pm 6 \mathrm{Ma}$ Wasigou gabbro intrusion, $758 \pm 37$ Ma Shimian diabase dyke [22], 800-810 Ma Xide diabase dyke [42], $746 \pm 10$ Ma Panzhihua gabbro [33], $812 \pm 3 \mathrm{Ma}$ Gaojiachun gabbro-diorite [31], $752 \pm 12$ Ma Shaba gabbro, and $820 \pm 13$ Ma Tongde gabbro [3]. They are the Neoproterozoic basic intrusions and dykes that intruded in the Meso-Neoproterozoic rift succession of the western YZB (Table S1). Certainly, many contemporaneous felsic magmatic rocks are also widely distributed, including the 751-768 Ma Kangdian granitic gneissic complex [3], $786 \pm 36$ Ma Shimian granite, $805 \pm 15$ Ma Xiasuozi granite [89], $775 \pm 8 \mathrm{Ma}$ and $764 \pm 9 \mathrm{Ma}$ Miyi gneissic complex [3,18], $760 \pm 4$ Ma Datian granodiorite [34], and $~ 751-768$ Ma Kangdian 
tonalite and granite [11]. In addition, the synchronous volcanics are also widely distributed in the YZB. For example, the $803 \pm 12$ Ma bimodal volcanic rocks in the Suxiong Formation [6], $799 \pm 8$ Ma basalts of Huangshuihe Group, $\sim 800$ Ma felsic tuffs of Chengjiang Formation [56,90], and $748 \pm 12$ Ma volcanics of the Liantuo Formation [91]. Based on the above-mentioned examples, the ca. 830-750 Ma magmatism is widely developed in the western YZB. As we know, Neoproterozoic anorogenic granitoids and basic-ultrabasic intrusions are also widespread around the northern and southern margin of the YZB (Table S1; $[11,45,46,85])$. These magmatic rocks may constitute a typical bimodal magmatic association, suggesting their genetic link with a continental rift environment, which is consistent with the viewpoint of Li et al. [3]. Our samples are most likely from a part of the ca. 830-750 Ma bimodal rift magmatism in the western YZB. Furthermore, most 821-825 Ma mafic-ultramafic intrusive complexes are discovered in the Yanbian area, suggesting that the Neoproterozoic magmatism in the YZB initiated at ca. 825 Ma [23,24].

\subsection{Petrogenesis of the $L T Q$ Basic Rocks}

\subsubsection{Alteration Effects on Chemical Compositions}

Major and trace elements for the LTQ rocks are listed in supplementary data Table S4. All samples in this study have undergone variable degrees of metamorphism and hydrothermal alterations, and are consistent with the high loss of ignition (LOI) values (average $2.58 \%$ ) and petrographic features (albitization of some plagioclases and hornblende altered to chlorite) (Figure 3). Thus, the effects of alteration on the chemical compositions of these rocks must be evaluated. Zirconium in the basic magmatic rocks is generally considered to be most immobile during low- to medium-grade alterations and can be used as an alteration-independent index of geochemical variations [92]. Therefore, bivariate plots of $\mathrm{Zr}$ against trace elements can be used for evaluating their mobility during alteration $[10,87,93]$. As shown in supplementary Figure S1, the elements, including $\mathrm{Y}, \mathrm{Nb}, \mathrm{Th}, \mathrm{La}, \mathrm{V}, \mathrm{Hf}, \mathrm{Rb}, \mathrm{Sr}$, and Ba are plotted against $\mathrm{Zr}$ to evaluate their mobility during alteration. Rare earth elements (REE, e.g., La), high field strength elements (HFSE, e.g., Y, Nb, Th and Hf) and siderophile elements (e.g., V) are all slightly correlated with $\mathrm{Zr}$, indicating that they were essentially immobile during alteration. In contrast, large ion lithophile elements (LILE, e.g., $\mathrm{Rb}$, Sr and $\mathrm{Ba}$ ) do not covariant with $\mathrm{Zr}$, suggesting varying degrees of mobility caused by the alteration. Although the correlation of $\mathrm{K}_{2} \mathrm{O}$ and $\mathrm{Na}_{2} \mathrm{O}$ with $\mathrm{MgO}$ contents (Figure 6) suggests the effects of alteration are minor, the sums of major element oxides for all samples are still recalculated to be $100 \%$ volatile free. Only the immobile elements (REE, HSFE, and siderophile elements) are used for geochemical classification and petrogenetic discussion.

\subsubsection{Fractional Crystallization}

It is generally considered that primary magmas of basaltic melts have $\mathrm{Ni}>400 \mathrm{ppm}$ and $\mathrm{Cr}>1000$ ppm [94], Mg\# > 73 [95]. The relatively low Cr concentrations (140-150 ppm) and Mg\# values (52.2-54.5) of the LTQ suggest that the rocks may have undergone significant fractionation of olivine and pyroxene. In the basic rocks, both $\mathrm{K}_{2} \mathrm{O}$ and $\mathrm{Al}_{2} \mathrm{O}_{3}$ are mainly enriched in plagioclase and amphibole. Most samples show a slight decrease in $\mathrm{CaO}, \mathrm{Al}_{2} \mathrm{O}_{3}$, and $\left(\mathrm{K}_{2} \mathrm{O}+\mathrm{Na}_{2} \mathrm{O}\right)$ with decreasing $\mathrm{MgO}$ contents (Figure $6 \mathrm{c}, \mathrm{e}$ ), suggesting that plagioclase fractionation crystallization is involved in the magma evolution. The weak negative $\mathrm{Sr}$ and $\mathrm{Eu}$ anomalies in trace element distribution patterns (Figure 8) also support this view. Meanwhile, the decrease in $\mathrm{K}_{2} \mathrm{O}, \mathrm{Al}_{2} \mathrm{O}_{3}$, and $\mathrm{TFe}_{2} \mathrm{O}_{3}$ with decreasing $\mathrm{MgO}$ may reflect the fractionation of amphibole, which is consistent with the petrographic features (Figure 3c,d). A negative correlation between $\mathrm{MgO}$ and $\mathrm{P}_{2} \mathrm{O}_{5}$ (Figure 6f) do not support the fractional crystallization of apatite. Moreover, $\mathrm{Fe}_{2} \mathrm{O}_{3}$ and $\mathrm{TiO}_{2}$ have different correlations with $\mathrm{MgO}$ (Figure $6 \mathrm{~b}, \mathrm{~d}$ ), which do not suggest the fractionation of Fe-Ti oxides. The samples show that while they are slightly fractionated in HREE (Figure 8), they are extremely enriched in zircon (Figure 5). These features precluded the fractional crystallization of garnet or its presence in residue, constraining a depth of less than $40 \mathrm{~km}$. 
The $\mathrm{Zr} / \mathrm{Y}$ ratios in the melts are mainly affected by the major phases of clinopyroxene, amphibole, and garnet [96]. As mentioned above, garnet was probably absent in the magma source, so it can be excluded. It is well known that the degree of compatible and incompatible elements is determined by the partition coefficients of the elements between mineral and melt (expressed as $\operatorname{mineral} /$ melt $D_{\text {element }}$, abbr. $\left.{ }^{\text {mineral }} D_{\text {element }}\right)$. Thus, if ${ }^{\text {mineral }} D_{\text {element }}<1$, the element is incompatible in the mineral, whereas ${ }^{\text {mineral }} D_{\text {element }}>1$ indicates that the element is compatible in the mineral. Based on previously published data, the partition coefficients of $\mathrm{Y}$ and $\mathrm{Zr}$ in the amphibole are ${ }^{\text {amphibole }} D_{\mathrm{Y}}=1$ and ${ }^{\text {amphibole }} D_{\mathrm{Zr}}=0.5$ in the basic rocks, respectively [96-98], suggesting that $Y$ contents remain constant in the melt if the amphibole dominates the fractionation process. Thus, the slope coefficient of $\mathrm{Zr} / \mathrm{Y}$ to $\mathrm{Zr}$ would approximate to the value of $1 / \mathrm{Y}$ when the amphibole fractionation occurs [99]. Here, we assume the $\mathrm{Y}$ content of $31.7 \mathrm{ppm}$ in sample 16LTQ-2. The sample was characterized by the highest $\mathrm{Mg \#}$ values and the lowest $\mathrm{Zr}$ content, and can therefore represent the $\mathrm{Y}$ content of the primary melt. However, the trend in Figure 10 argues against this probability, so the crystallization of the amphibole is also excluded. In contrast, the clinopyroxene dominated fractionation agrees well with this trend for the basic rocks (clinopyroxene $D_{\mathrm{Zr}}=0.1$ and ${ }^{\text {clinopyroxene }} D_{\mathrm{Y}}=0.5$, [96]) (Figure 10). Therefore, it can be inferred that the crystal fractionation of clinopyroxene may be controlled by the melt components of the Neoproterozoic basic magmatism in the western YZB.

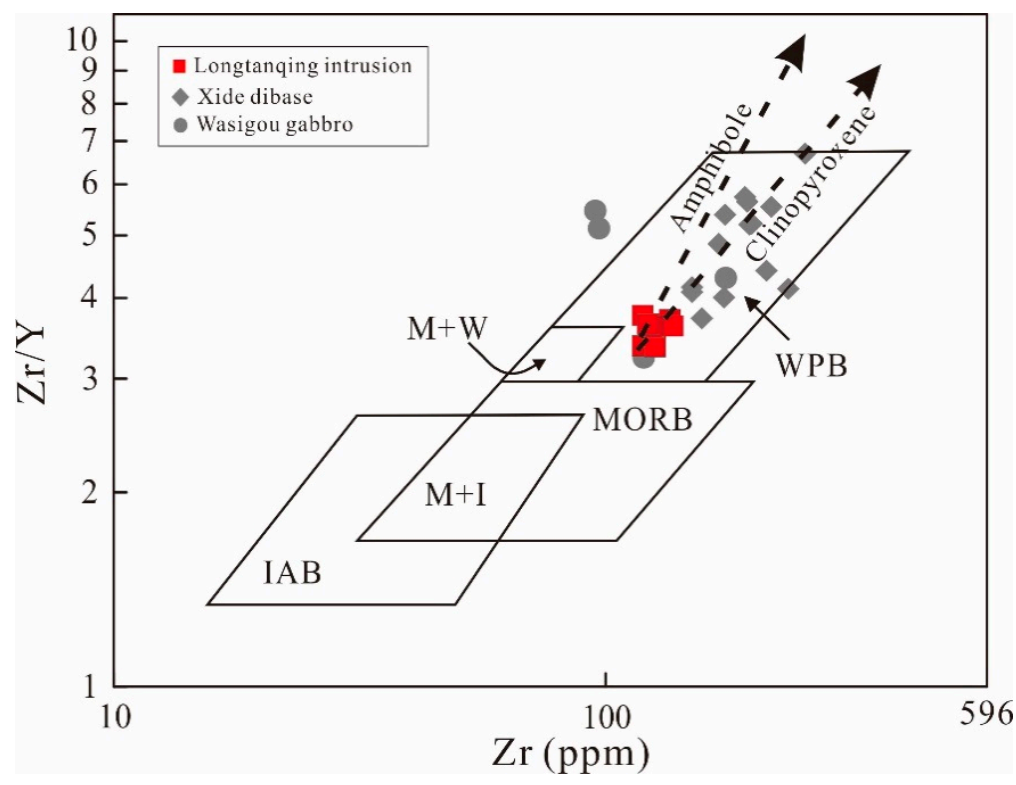

Figure 10. Geochemical discrimination diagram of $\mathrm{Zr} / \mathrm{Y}-\mathrm{Y}$ [96] for the Longtanqing, Xide [42], and Wasigou [22] in the western YZB. IAB-island arc basalt; WPB-within plate basalt; $\mathrm{M}+\mathrm{I}-\mathrm{MORB}$ and island arc basalt; $\mathrm{M}+\mathrm{W}-\mathrm{MORB}$ and within plate basalt.

\subsubsection{Source Characteristics of the LTQ}

The Neoproterozoic magmatic suites in the SCB display two age peaks of 830-800 Ma and 780-740 Ma [100]. Zircon Hf isotope data from the magmatic rocks (in particular for granitoids) indicate that the Neoproterozoic magmatism not only involved the remelting of the juvenile late Mesoproterozoic lithosphere (crust and lithospheric mantle), but also included the reconstruction of ancient crustal components within the rifting setting [100,101]. A detailed description can be seen in Table S1. Rocks from the LTQ can be compared to other Neoproterozoic magmatic rocks in the YZB, which are characterized by relatively large variations and positive zircon $\varepsilon_{\mathrm{Hf}}(\mathrm{t})$ values. Their initial ${ }^{176} \mathrm{Hf} /{ }^{177} \mathrm{Hf}$ ratios are significantly higher than those of the Archaean to Palaeoproterozoic basement [101-104], which suggests they were not derived from the reconstruction of preexisting old crust. Most zircons shown positive $\varepsilon_{\mathrm{Hf}}(\mathrm{t})$ values (1.6-9.4; Table S5), except at one negative point 
(-0.6) from the LTQ, indicating the source of these basic magma may relate to the mantle. In addition, these values are distinctively below the depleted mantle evolution line in the Hf evolution diagrams (Figure 9a), indicating the mantle magma sources also contain the addition of crustal materials. The involvement of pre-existing crustal materials is also evident by the presence of inherited zircons in the LTQ samples. However, the following lines of evidence showed that crustal contamination is insignificant, if any, in the generation of these basic intrusions. $\mathrm{Zr} / \mathrm{Hf}$ and $\mathrm{Nb} / \mathrm{Ta}$ ratios are insensitive to fractionation crystallization but sensitive to crustal input due to the contrast in values between mantle-derived melts and crustal materials $[105,106]$. The studied samples have nearly constant $\mathrm{Zr} / \mathrm{Hf}$ (34.0 to 39.4, with an average with 36.7) and $\mathrm{Nb} / \mathrm{Ta}$ (14.3 to 18.4, with an average with 15.9) ratios, which is similar to the OIB-like $\mathrm{Na} / \mathrm{Ta}$ and $\mathrm{Zr} / \mathrm{Hf}$ ratios (OIB with $\mathrm{Nb} / \mathrm{Ta}=15.9 \pm 0.6$ and $\mathrm{Zr} / \mathrm{Hf}=36.3$ ) and inconsistent with the crustal contamination. Furthermore, the lack of country rock xenoliths in the intrusions does not support significant crustal contamination.

Zircon Hf isotopes from the LTQ display $\varepsilon_{\mathrm{Hf}}(\mathrm{t})$ values from 1.6 to 9.4, corresponding to Hf depleted mantle model ages ( $\mathrm{T}_{\mathrm{DM} 1}$ ) of 1.3-1.0 Ga (Figure 9), which suggest that the initial magmas of the LTQ might be generated by a partial melting of the late Mesoproterozoic juvenile lithosphere. The presence of inherited zircons (991-1190 Ma) also support this interpretation (Figure 4). The other Neoproterozoic basic rocks in the western YZB exhibit similar Hf isotopic compositions (Figure 9a), such as the Kangdian bimodal plutons emplaced at 750-760 Ma, and exhibit zircon $\varepsilon_{\mathrm{Hf}}(\mathrm{t})$ values as 3.5-9.9, with the Hf modal ages of 0.9-1.2 Ga. [11]. In addition, the basic plutons at 800-820 Ma in the western YZB, such as Tongde, Gaojiachun, and Lengshuiqing, are mainly composed of gabbros and the $\varepsilon_{\mathrm{Hf}}(\mathrm{t})$ values are also positive from 5.3 to 7.0 , with the $\mathrm{T}_{\mathrm{DM} 1}$ of 1.1-1.2 Ga [31,35]. However, the Guandaoshan dioritic pluton, which is the only published one that can be considered to come from the depleted mantle, represents high zircon $\varepsilon_{\mathrm{Hf}}(\mathrm{t})$ values (11.3-17.7) and consistent $\mathrm{U}-\mathrm{Pb}$ ages and $\mathrm{T}_{\mathrm{DM} 1}$ (Figure 9a; [86]). Thus, the Neoproterozoic magmatism in the western YZB extensively involved the remelting of the late Mesoproterozoic juvenile lithosphere and the limited accretion of juvenile crust [100]. Furthermore, the low $\delta^{18} \mathrm{O}$ values are associated with the 830-740 Ma zircons in the region [11], suggesting the production of these magmas may be associated with high-T water-rock reaction in the rift setting.

Traditionally, zircon trace element data can be an efficient tracer to probe the composition and temperature of the melt $[78,107,108]$. The REE patterns of the zircons from the samples show the steep MREE to HREE, with $(\mathrm{Lu} / \mathrm{Gd})_{\mathrm{N}}$ ratios of 7.6-42.4, which are regarded as the typical features of magmatic origin zircons forming in the source without garnet (Figure $5 ;[78,109])$. The zircons also display obviously positive Ce anomalies $\left(\mathrm{Ce} / \mathrm{Ce}_{\mathrm{N}}{ }^{*} \gg 1\right.$, Figure 5 and Table S3), indicating that they were crystallized from the melt with a high oxidation fugacity [110]. This is particularly conductive to the precipitation of the $\mathrm{Fe}, \mathrm{Cu}$ and other ore-forming elements, consistent with the widespread $\mathrm{Fe}-\mathrm{Cu}$ deposits in this region. In addition, the zircons exhibit relatively variable and low negative $\mathrm{Eu}$ anomalies $\left(\mathrm{Eu} / \mathrm{Eu}_{\mathrm{N}}{ }^{*}=0.08-0.71\right.$, Figure 5), which suggest a late crystallizing phase that formed after plagioclase crystallization [107]. Ti contents in these zircons range from 1.99 to $40.1 \mathrm{ppm}$, yielding the zircon crystallization temperatures of $616-880^{\circ} \mathrm{C}$ (Table S3), which are close to the zircon saturation temperatures [111]. It is well known that it is hard for zirconium contents to reach the saturation level in basic magmas [111], and this may be caused by fluid/melt metasomatism from the subducted slab or crustal contamination during upwelling.

The geochemical features of LTQ samples have low $\mathrm{SiO}_{2}(49.83-50.71 \mathrm{wt} \%)$ contents, which indicate the mantle affinity. Furthermore, their relatively high $\mathrm{MgO}(5.91-6.53 \mathrm{wt} \%)$ and $\mathrm{Cr}$ (140-150 ppm) contents also support their mantle source. In addition, in the $\mathrm{Nb} / \mathrm{Ta}-\mathrm{Th} / \mathrm{Yb}$ and $\mathrm{Nb} / \mathrm{Ta}-\mathrm{Th}$ diagrams, the LTQ, Wasigou gabbros, and Xide diabase exhibit relative low but varied $\mathrm{Th}$ and $\mathrm{Th} / \mathrm{Yb}$ ratios, as well as a negative correlation between $\mathrm{Nb} / \mathrm{Th}$ and $\mathrm{Th}$, which is similar to the basic-ultrabasic rocks from Hannan Massif, Northwestern YZB (Figure 11). These suggest the mantle sources of these basic rocks may have been reconstructed by the subduction. The continental basalts are generally considered to be generated by the interaction between the asthenosphere and 
lithosphere [112]. The $\mathrm{Nb} / \mathrm{La}$ ratio is quite different in the sub-continental lithospheric mantle (SCLM) and asthenospheric mantle, so it can be used as a distinguishing indicator [42]. Traditionally, the asthenospheric mantle-derived melts are generally characterized by high $\mathrm{Nb} / \mathrm{La}$ ratios, varying from 0.9 (N-MORB) to 1.3 (OIB and E-MORB) [80]. On the contrary, the SCLM-derived melts display low $\mathrm{Nb} / \mathrm{La}$ ratios, and are equivalent to that of continental crust [112]. The LTQ have relatively constant $\mathrm{Nb} /$ La ratios from 0.60 to 0.86 with an average of 0.71 . These ratios are significantly less than asthenosphere but close to or slightly higher than SCLM-derived melts. However, the significant $\mathrm{Nb}-\mathrm{Ta}-\mathrm{Ti}$ depletion in the trace element spider diagrams of the samples (Figure 8) indicates that the SCLM-derived melts have been reconstructed by the subduction or assimilated by crustal materials. Thus, the arc signatures of LTQ and other basic-ultrabasic rocks in the YZB could be inherited from juvenile lithosphere mantle/crust components which formed during Greenville Orogen in SCB [39]. The asthenospheric mantle upwelling under the effect of mantle plume is considered to have supplied the heat and material to induce SCLM melting during Neoproterozoic. The SCLM source has been reconstructed by the subduction, then overprinted in the arc signature. Afterward, the melt components are controlled by the fractionation of clinopyroxene and plagioclase with minor amphibole under high oxidation fugacity. The absence of garnet in the residue phase or in the fractionation process indicates that the depth of magmatism production was less than $40 \mathrm{~km}$.
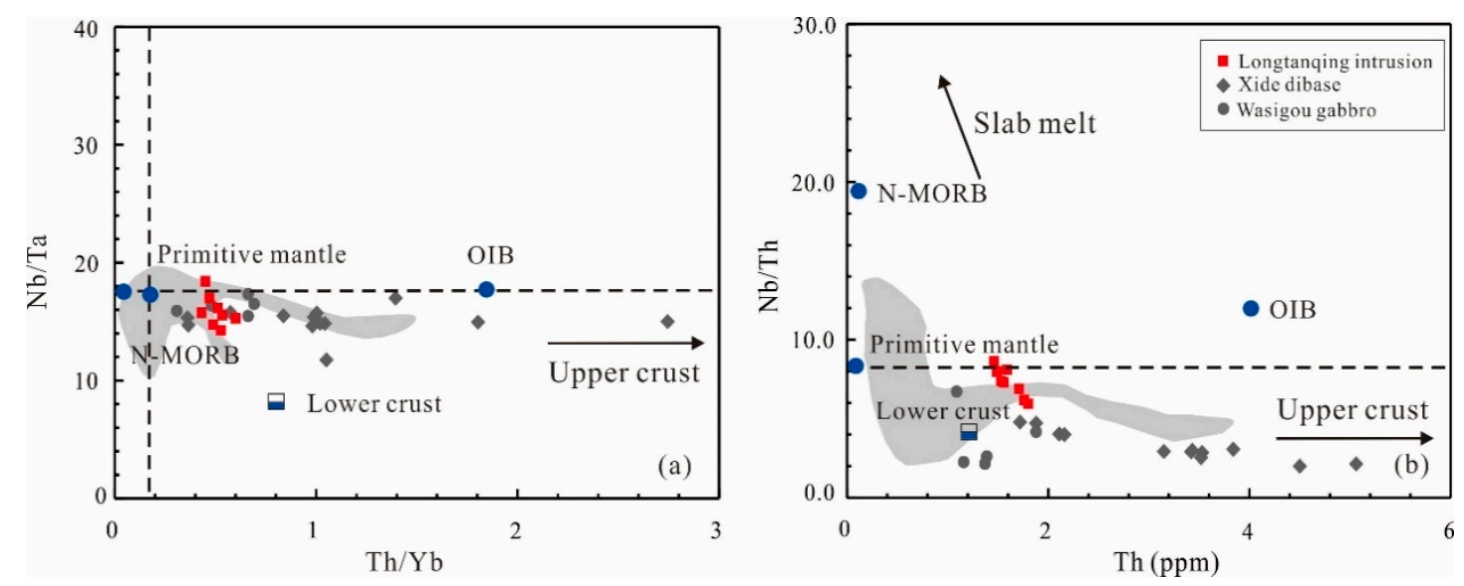

Figure 11. Plots of $\mathrm{Nb} / \mathrm{Ta}$ vs. $\mathrm{Th} / \mathrm{Yb}(\mathbf{a})$ and $\mathrm{Nb} / \mathrm{Th}$ vs. Th (b) for the magmatic rocks in the Longtanqing, Xide [42] and Wasigou [22], western YZB, SW China. Values of N-MORB, OIB and Primitive mantle are from [80]. Values of the upper and lower crust are from [113]. The shaded areas outline the ranges of compositions for basic-ultrabasic rocks from the Hannan Massif of northwestern YZB with data source from [45].

\subsection{Tectonic Implications}

The LTQ, Xide, and Wasigou basic rocks of western YZB and Hannan basic-ultrabasic rocks of northwestern YZB are characterized by negative $\mathrm{Nb}$ and $\mathrm{Ta}$ anomalies on their trace element spidergrams (Figure 8), which is considered to be the main feature of the typical arc basalts. Zhao and Zhou [33] obtained this similar arc-like geochemical features from Panzhihua gabbros, and they interpreted that it came from an arc environment. However, it is generally accepted that the $\mathrm{Nb}$ and Ta depletions also occur in many non-arc environments, like rift, these features may be derived from subduction-modified SCLM, contaminated by crustal materials, or inherited from the arc-derived crust $[6,100,114-117]$. Therefore, the characters of depletions in $\mathrm{Nb}$ and $\mathrm{Ta}$ cannot be used as the only criterion to distinguish between arc basalts and intraplate rift basalts; many other aspects of the evidence must be considered. 
For the basic rocks of the YZB (e.g., the LTQ), there is geochemical evidence against the arc origin: (1) all the samples that are plotted in the field between the OIB and IAB (Figure 8) distinctly show that the contents of most of the trace elements are relatively higher than those of IAB; (2) like LTQ, the contents of $\mathrm{Cr}$ (140 to $150 \mathrm{ppm})$ and $\mathrm{TiO}_{2}$ (1.93 to $\left.2.34 \mathrm{wt} \%\right)$ are also clearly higher than those of typical IAB $\left(\mathrm{Cr}=50 \mathrm{ppm} ; \mathrm{TiO}_{2}=0.84 \mathrm{wt} \%\right)[94,118]$; (3) the Ti/V ratios can be an efficient tracer to probe into the tectonic setting of basalts, because these ratios are affected by their source characters, oxygen fugacity, the degrees of crystallization, and partial melting of their magmas [118]. The LTQ samples display the high Ti/V ratios that are between 37.3 and 47.5 (mostly $>20$ ), which are significantly higher than that of typical IABs $(<20)$. On the plot of the Ti-V diagram, all samples are plotted into the field of continental flood basalt, similar to the other basic rocks of the YZB (Figure 12); (4) the diagram of $\mathrm{Zr} / \mathrm{Y}$ vs. $\mathrm{Zr}$ can also be used to discriminate the tectonic setting of within plate basalt (WPB), MORB, and IAB [96]. In this research, the $\mathrm{Zr} / \mathrm{Y}$ ratios (3.37-3.75) of the LTQ are comparable to other basic rocks, and in the $\mathrm{Zr}-\mathrm{Zr} / \mathrm{Y}$ diagram, all samples are plotted in the field of WPB rather than the IAB (Figure 10), and the same results are also shown in the $\mathrm{Zr}-\mathrm{Ti}$ and $\mathrm{Ti}-\mathrm{Zr}-\mathrm{Y}$ diagrams (Figure 13a,b). In addition, this view is further supported by the discriminant diagram of Wang [119]; most basic rocks from the YZB fall in the field of continental WPB and IAB (Figure 13c), which represent the obvious dual characteristics of these basic rocks. However, their geochemical characteristics share many affinities to extension setting, except for the depletion of $\mathrm{Nb}$ and Ta. Thus, the basic rocks of YZB should be interpreted as generational from the SCLM-derived melts in a rift environment. Furthermore, the nearly N-S trend of the LTQ, Xide, and Wasigou basic rocks and the roughly E-W trending Hannan basic-ultrabasic rocks are sub-parallel to the Kangdian and Bikou-Hannan rift, respectively (Figure 1), which is also consistent with this interpretation.

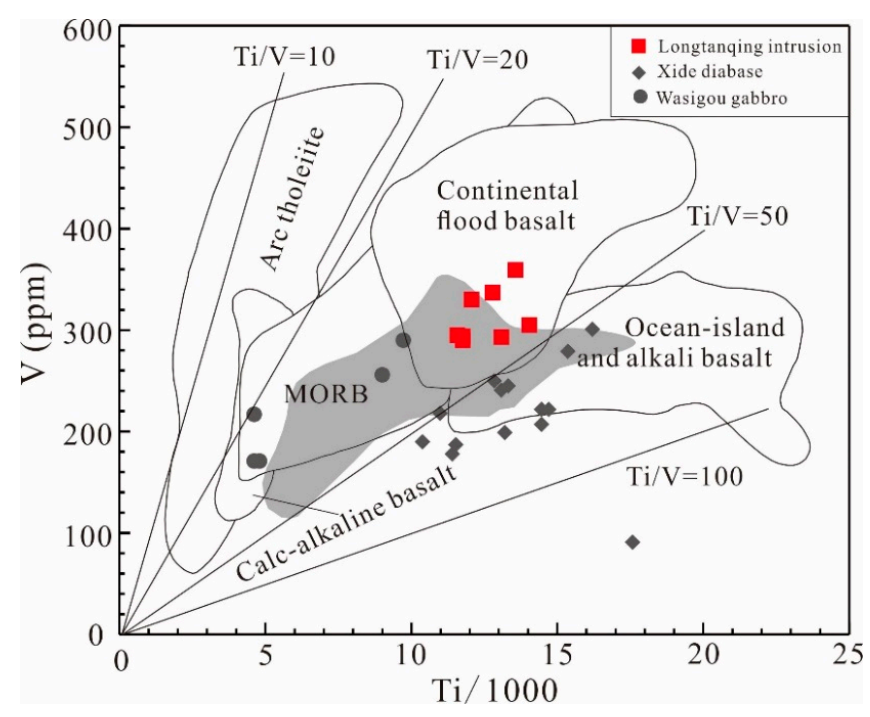

Figure 12. V-Ti discrimination diagram of [120] for the basic rocks from Longtanqing, Xide, and Wasigou, western YZB. The shaded areas outline the ranges of compositions for basic-ultrabasic rocks from the Hannan Massif of the northwestern YZB with data source from [45]. 


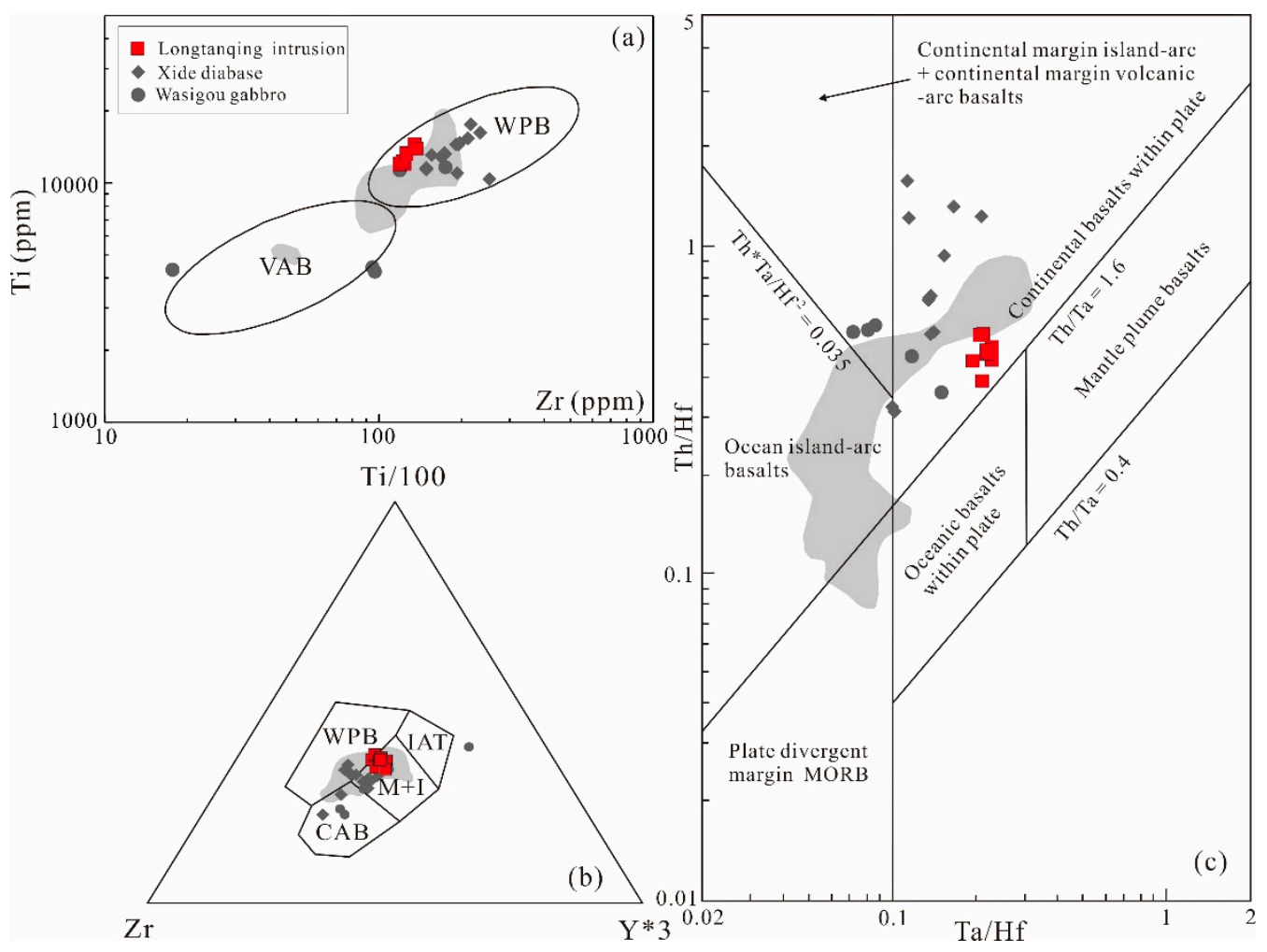

Figure 13. Tectonic discrimination diagrams for the magmatic rocks in the western Yangtze block. (a) The $\mathrm{Zr}-\mathrm{Ti}$ diagram is after [121]; (b) the Ti-Zr-Y diagram is after [122]; (c) the Ta/Hf-Th/Hf diagram is after [119]. WPB — within plate basalt; VAB — volcanic arc basalt; IAT—island arc tholeiite; $\mathrm{CAB}$ - calc-alkaline basalt; $\mathrm{M}+\mathrm{I}-\mathrm{MORB}$ and island arc tholeiite. The shaded areas outline the ranges of compositions for basic-ultrabasic rocks from the Hannan Massif of northwestern YZB with data source from [45].

It is well known that the Rodinia supercontinent was assembled between 1300 and 900 Ma through the Grenville and other global synchronous orogenic events [4]. As a part fragment of Rodinia, the YZB is considered to be located between Australia and North America [4,39], or on the periphery of the supercontinent during the assembly of Rodina [32]. In any case, the YZB was in an active continent margin setting at the late Mesoproterozoic to early Neoproterozoic, and the widespread Sibao Orogeny between Yangtze and Cathaysia is commonly regarded as one of the global Grenville-aged orogeny (Figure 14a; [123,124]). The old inherited zircons of 16LTQ-2 have ${ }^{206} \mathrm{~Pb} /{ }^{238} \mathrm{U}$ age of $991-1190 \mathrm{Ma}$, and are contemporaneous with the peaks of the Sibao Orogeny $[51,123,124]$. We thus suggest the apparent arc-like geochemical signatures of the magmatic rocks were derived from the convergent tectonic setting during the Sibao Orogeny. The wildly distributed late Mesoproterozoic zircon model ages (1.0-1.3 Ga; Tables S1 and S4) of the basic rocks also indicate the presence of juvenile lithosphere growth at that time in the YZB $[11,100]$. However, there are widespread 830-750 Ma bimodal magmatic rocks including the LTQ, suggesting a possible continental rift environment at that time [125]. Based on the geochemical and $\mathrm{Nd}$ isotopic data, the Wasigou ( 779 Ma) and Xide (800-810 Ma) basic rocks in the Kangdian region were most likely formed in a continental rift environment [22,42]. The discovery of ca. $800 \mathrm{Ma}$ high-MgO Tongde picrite is also confirmed by the presence of a hot mantle plume beneath the SCB [21]. The recently identified A-type granites of $\sim 780$ Ma Mianning granites and $\sim 801$ Ma Xiatianba granites have been demonstrated to be produced within an intraplate extension environment [126]. The widespread adakitic rocks from the Mopanshan (780 Ma), Xuelongbao (750 Ma), and Datian (760 Ma) are also considered to be derived from a juvenile, thickened lower crust in an intracontinental extension setting [127]. Recent studies confirm that the sedimentary history of the 
Kangdian Rift can be well correlated with the Nanhua Rift [28]. A SHRIMP zircon U-Pb age of tuffs from the lowermost part of the Luliang formation is $819 \pm 9 \mathrm{Ma}$, which represents the initiation of the Kangdian Rift [90]. More intriguingly, the latest proposed tectonic model and filling pattern of the Kangdian Rift $[90,128]$ are comparable to those of the East Africa Rift, a typical continental rift [129]. This evidence suggests that the YZB was a continental rift environment during the Neoproterozoic and the extensive magmatic rocks are triggered by these events (Figure 14b).
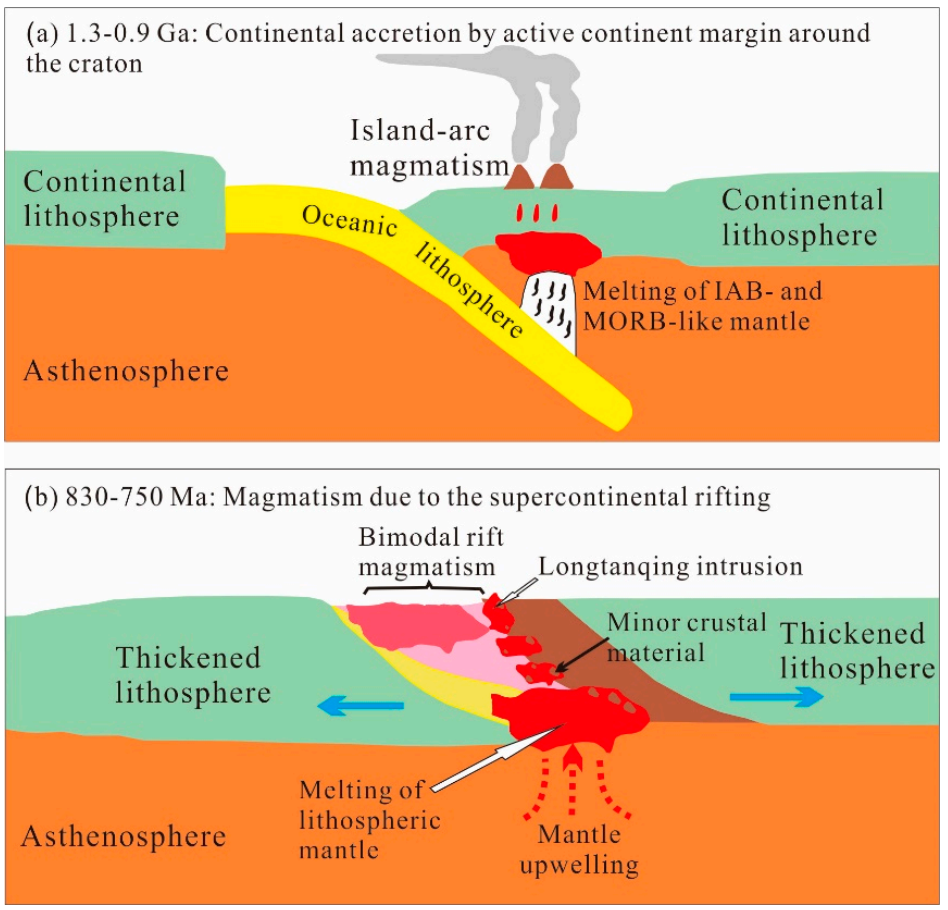

Figure 14. A sketch cartoon showing the tectonic evolution of the western YZB from ca. 1300 Ma to $750 \mathrm{Ma}$ (modified after [12]). Detailed description in the main text.

There is a wide distribution of Neoproterozoic basic rocks in the western YZB (Table S1), which underwent the reconstruction of the Mesoproterozoic subducted melt/fluid and displayed dual geochemical characters, and they are considered to be formed in the continental rifting environment, instead of the arc-related basalts. Combined with the synchronous felsic magmatism and typical rift deposition in this region, this suggests that the Neoproterozoic continental rifting once occurred in the YZB. In addition, the widely distributed Neoproterozoic anorogenic magmatism also occurred in other Rodinia blocks, such as Australia [10,116,130,131], Laurentia [2,14,132], India [133,134], South Africa $[5,135]$, and Tarim $[13,136]$. All these observations indicate that the Neoproterozoic anorogenic magmatism (including LTQ basic rocks) and continental rifting in the YZB belong to a series of global rifting magmatic events related to the breakup of the Rodinia supercontinent.

\section{Conclusions}

Based on geochronological, geochemical, and Hf isotopic studies of the LTQ samples, we draw the following conclusions:

(1) LA-ICPMS zircon U-Pb dating yielded the $780 \mathrm{Ma}$ emplacement age of the Longtanqing intrusions, which are coeval with the widespread Neoproterozoic magmatic magmatism (830-750 Ma) in the western Yangtze Block.

(2) The Longtanqing samples belong to the tholeiitic series. They are generated by partial melting of the SCLM and may have been reconstructed by the Mesoproterozoic subduction. An absence of garnet in the residue phase constrain a depth of less than $40 \mathrm{~km}$ for the Neoproterozoic magmatism in 
the western Yangtze Block, and the melt compositions are controlled by the crystal fractionation of the dominant clinopyroxene and plagioclase with minor amphibole under high $f \mathrm{O}_{2}$ conditions. They are most likely formed in a continental rift setting, rather than an arc-related setting.

(3) Zircon Hf single-stage model ages (972-1285 Ma) and the occurrences of inherited zircons with ages of 991-1190 Ma provide firm evidence for Mesoproterozoic juvenile crust involved in the shaping of the Longtanqing diabases trace elemental arc signature.

(4) The Yangtze Block once experienced the Neoproterozoic continental rifting, and extensively developed rift-related magmatism, generating the $\sim 780$ Ma Longtanqing intrusion, which is likely recorded in the response to the mantle activity during the breakup of Rodinia.

Supplementary Materials: The following are available online at http:/ / www.mdpi.com/2075-163X/8/6/228/s1, Figure S1: Diagrams of $\mathrm{Y}, \mathrm{Nb}, \mathrm{Th}, \mathrm{La}, \mathrm{V}, \mathrm{Hf}, \mathrm{Rb}, \mathrm{Sr}$, and Ba vs. Zr to evaluate the mobility of these elements during alteration, Table S1: Summary of published Neoproterozoic zircon $\mathrm{U}-\mathrm{Pb}$ ages and corresponding $\mathrm{Lu}-\mathrm{Hf}$ isotopes for basic rocks in YZB, Table S2: LA-ICPMS U-Pb isotopic compositions for zircons from the LTQ, Table S3: Trace elements (ppm) in zircons from the LTQ, Table S4: Major and trace elements data of the LTQ, Table S5: Lu-Hf isotopic data for zircons from the LTQ.

Author Contributions: S.S., X.Y., and L.L. conceived and designed the experiments; W.L. and J.C. took part to the field campaigns; E.G. took part in the discussion; S.S. and L.L. analyzed the data; S.S., X.Y., and L.L. wrote the paper.

Acknowledgments: This study is supported by the National Key R\&D Program of China (No. 2016YFC0600404), the National Science Foundation of China (Nos. 41673040, 41502067), the project of China Geological Survey (DD20160017), and the Opening Foundation of State Key Laboratory of Continental Dynamics, Northwest University. Thanks are due to Fangyue Wang for his assistance with LA-ICPMS dating.

Conflicts of Interest: The authors declare no conflict of interest.

\section{References}

1. Powell, C.M.; Preiss, W.V.; Gatehouse, C.G.; Krapez, B.; Li, Z.X. South Australian Record of a Rodinian Epicontinental Basin and Its Mid-Neoproterozoic Breakup (Similar-to-700 Ma) to Form the Palaeo-Pacific Ocean. Tectonophysics 1994, 237, 113-140. [CrossRef]

2. Park, J.K.; Buchan, K.L.; Harlan, S.S. A Proposed Giant Radiating Dyke Swarm Fragmented by the Separation of Laurentia and Australia Based on Paleomagnetism of Ca. 780 Ma Mafic Intrusions in Western North-America. Earth Planet. Sci. Lett. 1995, 132, 129-139. [CrossRef]

3. Li, Z.X.; Li, X.H.; Kinny, P.D.; Wang, J.; Zhang, S.; Zhou, H. Geochronology of Neoproterozoic syn-rift magmatism in the Yangtze Craton, South China and correlations with other continents: Evidence for a mantle superplume that broke up Rodinia. Precambrian Res. 2003, 122, 85-109. [CrossRef]

4. Li, Z.X.; Bogdanova, S.V.; Collins, A.S.; Davidson, A.; De Waele, B.; Ernst, R.E.; Fitzsimons, I.; Fuck, R.A.; Gladkochub, D.P.; Jacobs, J. Assembly, configuration, and break-up history of Rodinia: A synthesis. Precambrian Res. 2008, 160, 179-210. [CrossRef]

5. Frimmel, H.E.; Zartman, R.E.; Spath, A. The Richtersveld Igneous Complex, South Africa: U-Pb zircon and geochemical evidence for the beginning of Neoproterozoic continental breakup. J. Geol. 2001, 109, 493-508. [CrossRef]

6. Li, X.H.; Li, Z.X.; Zhou, H.W.; Liu, Y.; Kinny, P.D. U-Pb zircon geochronology, geochemistry and Nd isotopic study of Neoproterozoic bimodal volcanic rocks in the Kangdian Rift of South China: Implications for the initial rifting of Rodinia. Precambrian Res. 2002, 113, 135-154. [CrossRef]

7. Li, X.H.; Li, W.X.; Li, Z.X.; Liu, Y. 850-790 Ma bimodal volcanic and intrusive rocks in northern Zhejiang, South China: A major episode of continental rift magmatism during the breakup of Rodinia. Lithos 2008, 102, 341-357. [CrossRef]

8. $\quad$ Ling, W.L.; Gao, S.; Zhang, B.R.; Li, H.M.; Liu, Y.; Cheng, J.P. Neoproterozoic tectonic evolution of the northwestern Yangtze craton, South China: Implications for amalgamation and break-up of the Rodinia Supercontinent. Precambrian Res. 2003, 122, 111-140. [CrossRef]

9. Wang, X.C.; Li, X.H.; Li, W.X.; Li, Z.X. Ca. 825 Ma komatiitic basalts in South China: First evidence for $>1500$ degrees C mantle melts by a Rodinian mantle plume. Geology 2007, 35, 1103-1106. [CrossRef] 
10. Wang, X.C.; Li, X.H.; Li, Z.X.; Liu, Y.; Yang, Y.H. The Willouran basic province of South Australia: Its relation to the Guibei large igneous province in South China and the breakup of Rodinia. Lithos 2010, 119, 569-584. [CrossRef]

11. Zheng, Y.F.; Zhang, S.B.; Zhao, Z.F.; Wu, Y.B.; Li, X.H.; Li, Z.X.; Wu, F.Y. Contrasting zircon Hf and O isotopes in the two episodes of Neoproterozoic granitoids in South China: Implications for growth and reworking of continental crust. Lithos 2007, 96, 127-150. [CrossRef]

12. Zheng, Y.F.; Wu, R.X.; Wu, Y.B.; Zhang, S.B.; Yuan, H.L.; Wu, F.Y. Rift melting of juvenile arc-derived crust: Geochemical evidence from Neoproterozoic volcanic and granitic rocks in the Jiangnan Orogen, South China. Precambrian Res. 2008, 163, 351-383. [CrossRef]

13. Xu, Z.Q.; He, B.Z.; Zhang, C.L.; Zhang, J.X.; Wang, Z.M.; Cai, Z.H. Tectonic framework and crustal evolution of the Precambrian basement of the Tarim Block in NW China: New geochronological evidence from deep drilling samples. Precambrian Res. 2013, 235, 150-162. [CrossRef]

14. McClellan, E.; Gazel, E. The Cryogenian intra-continental rifting of Rodinia: Evidence from the Laurentian margin in eastern North America. Lithos 2014, 206, 321-337. [CrossRef]

15. Li, X.H.; Li, Z.X.; Ge, W.C.; Zhou, H.W.; Li, W.X.; Liu, Y.; Wingate, M.T.D. Reply to the comment: Mantle plume-, but not arc-related Neoproterozoic magmatism in South China. Precambrian Res. 2004, 132, 405-407. [CrossRef]

16. Wang, X.L.; Zhou, J.C.; Qiu, H.S.; Gao, H.F. Comment on “Neoproterozoic granitoids in South China: Crustal melting above a mantle plume at ca. 825 Ma?" by Xian-Hua Li et al. [Precambrian Res. 122 (2003) 45-83]. Precambrian Res. 2004, 132, 401-403. [CrossRef]

17. Zhou, M.F.; Yan, D.P.; Kennedy, A.K.; Li, Y.Q.; Ding, J. SHRIMP U-Pb zircon geochronological and geochemical evidence for Neoproterozoic arc-magmatism along the western margin of the Yangtze Block, South China. Earth Planet. Sci. Lett. 2002, 196, 51-67. [CrossRef]

18. Zhou, M.F.; Kennedy, A.K.; Sun, M.; Malpas, J.; Lesher, C.M. Neoproterozoic arc-related mafic intrusions along the northern margin of South China: Implications for the accretion of Rodinia. J. Geol. 2002, 110, 611-618. [CrossRef]

19. Li, Z.X.; Li, X.H.; Kinny, P.D.; Wang, J. The breakup of Rodinia: Did it start with a mantle plume beneath South China? Earth Planet. Sci. Lett. 1999, 173, 171-181. [CrossRef]

20. Li, X.H.; Li, Z.X.; Ge, W.C.; Zhou, H.W.; Li, W.X.; Liu, Y.; Wingate, M.T.D. Neoproterozoic granitoids in South China: Crustal melting above a mantle plume at ca. 825 Ma? Precambrian Res. 2003, 122, 45-83. [CrossRef]

21. Li, X.H.; Zhu, W.G.; Zhong, H.; Wang, X.C.; He, D.F.; Bai, Z.J.; Liu, F. The Tongde Picritic Dikes in the Western Yangtze Block: Evidence for Ca. 800-Ma Mantle Plume Magmatism in South China during the Breakup of Rodinia. J. Geol. 2010, 118, 509-522. [CrossRef]

22. Lin, G.C.; Li, X.H.; Li, W.X. SHRIMP U-Pb zircon age, geochemistry and Nd-Hf isotope of Neoproterozoic mafic dyke swarms in western Sichuan: Petrogenesis and tectonic significance. Sci. China Ser. D 2007, 50, 1-16. [CrossRef]

23. Zhu, W.G.; Zhong, H.; Deng, H.L.; Wilson, A.H.; Liu, B.G.; Li, C.Y.; Qin, Y. SHRIMP zircon U-Pb age, geochemistry, and Nd-Sr isotopes of the Gaojiacun mafic-ultramafic intrusive complex, Southwest China. Int. Geol. Rev. 2006, 48, 650-668. [CrossRef]

24. Zhu, W.G.; Zhong, H.; Li, X.H.; Liu, B.G.; Deng, H.L.; Qin, Y. Ar-40-Ar-39 age, geochemistry and Sr-Nd-Pb isotopes of the Neoproterozoic Lengshuiqing $\mathrm{Cu}-\mathrm{Ni}$ sulfide-bearing mafic-ultramafic complex, SW China. Precambrian Res. 2007, 155, 98-124. [CrossRef]

25. Wang, X.C.; Li, X.H.; Li, W.X.; Li, Z.X.; Liu, Y.; Yang, Y.H.; Liang, X.R.; Tu, X.L. The Bikou basalts in the northwestern Yangtze block, South China: Remnants of 820-810 Ma continental flood basalts? GSA Bull. 2008, 120, 1478-1492. [CrossRef]

26. Wang, X.C.; Li, X.H.; Li, W.X.; Li, Z.X. Variable involvements of mantle plumes in the genesis of mid-Neoproterozoic basaltic rocks in South China: A review. Gondwana Res. 2009, 15, 381-395. [CrossRef]

27. Wang, Q.; Wyman, D.A.; Li, Z.X.; Bao, Z.W.; Zhao, Z.H.; Wang, Y.X.; Jian, P.; Yang, Y.H.; Chen, L.L. Petrology, geochronology and geochemistry of ca. 780 Ma A-type granites in South China: Petrogenesis and implications for crustal growth during the breakup of the supercontinent Rodinia. Precambrian Res. 2010, 178, 185-208. [CrossRef]

28. Wang, J.; Li, Z.X. History of Neoproterozoic rift basins in South China: Implications for Rodinia break-up. Precambrian Res. 2003, 122, 141-158. [CrossRef] 
29. Wang, X.C.; Li, X.H.; Li, Z.X.; Li, Q.L.; Tang, G.Q.; Gao, Y.Y.; Zhang, Q.R.; Liu, Y. Episodic Precambrian crust growth: Evidence from $\mathrm{U}-\mathrm{Pb}$ ages and $\mathrm{Hf}-\mathrm{O}$ isotopes of zircon in the Nanhua Basin, central South China. Precambrian Res. 2012, 222, 386-403. [CrossRef]

30. Li, X.H.; Li, Z.X.; Li, W.X. Detrital zircon U-Pb age and Hf isotope constrains on the generation and reworking of Precambrian continental crust in the Cathaysia Block, South China: A synthesis. Gondwana Res. 2014, 25, 1202-1215. [CrossRef]

31. Zhou, M.F.; Ma, Y.X.; Yan, D.P.; Xia, X.P.; Zhao, J.H.; Sun, M. The Yanbian terrane (Southern Sichuan Province, SW China): A neoproterozoic are assemblage in the western margin of the Yangtze block. Precambrian Res. 2006, 144, 19-38. [CrossRef]

32. Zhou, M.F.; Yan, D.P.; Wang, C.L.; Qi, L.; Kennedy, A. Subduction-related origin of the 750 Ma Xuelongbao adakitic complex (Sichuan Province, China): Implications for the tectonic setting of the giant Neoproterozoic magmatic event in South China. Earth Planet. Sci. Lett. 2006, 248, 286-300. [CrossRef]

33. Zhao, J.H.; Zhou, M.F. Geochemistry of Neoproterozoic mafic intrusions in the Panzhihua district (Sichuan Province, SW China): Implications for subduction-related metasomatism in the upper mantle. Precambrian Res. 2007, 152, 27-47. [CrossRef]

34. Zhao, J.H.; Zhou, M.F. Neoproterozoic adakitic plutons and arc magmatism along the western margin of the Yangtze Block, South China. J. Geol. 2007, 115, 675-689. [CrossRef]

35. Zhao, J.H.; Zhou, M.F.; Yan, D.P.; Yang, Y.H.; Sun, M. Zircon Lu-Hf isotopic constraints on Neoproterozoic subduction-related crustal growth along the western margin of the Yangtze Block, South China. Precambrian Res. 2008, 163, 189-209. [CrossRef]

36. Zhao, J.H.; Zhou, M.F.; Yan, D.P.; Zheng, J.P.; Li, J.W. Reappraisal of the ages of Neoproterozoic strata in South China: No connection with the Grenvillian orogeny. Geology 2011, 39, 299-302. [CrossRef]

37. Meng, E.; Liu, F.L.; Du, L.L.; Liu, P.H.; Liu, J.H. Petrogenesis and tectonic significance of the Baoxing granitic and mafic intrusions, southwestern China: Evidence from zircon $\mathrm{U}-\mathrm{Pb}$ dating and $\mathrm{Lu}-\mathrm{Hf}$ isotopes, and whole-rock geochemistry. Gondwana Res. 2015, 28, 800-815. [CrossRef]

38. Wang, X.L.; Zhou, J.C.; Qiu, J.S.; Gao, J.F. Geochemistry of the Meso- to Neoproterozoic basic-acid rocks from Hunan Province, South China: Implications for the evolution of the western Jiangnan orogen. Precambrian Res. 2004, 135, 79-103. [CrossRef]

39. Li, Z.X.; Zhang, L.H.; Powell, C.M. South China in Rodinia-Part of the Missing Link between Australia East Antarctica and Laurentia. Geology 1995, 23, 407-410. [CrossRef]

40. Li, X.H.; Wang, X.C.; Li, W.X.; Li, Z.X. Petrogenesis and tectonic significance of Neoproterozoic basaltic rocks in South China: From orogenesis to intracontinental rifting. Geochimica 2008, 37, 382-398.

41. Wang, X.C.; Li, Z.X.; Li, X.H.; Li, Q.L.; Zhang, Q.R. Geochemical and Hf-Nd isotope data of Nanhua rift sedimentary and volcaniclastic rocks indicate a Neoproterozoic continental flood basalt provenance. Lithos 2011, 127, 427-440. [CrossRef]

42. Cui, X.Z.; Jiang, X.S.; Wang, J.; Wang, X.C.; Zhuo, J.W.; Deng, Q.; Liao, S.Y.; Wu, H.; Jiang, Z.F.; Wei, Y.A. Mid-Neoproterozoic diabase dykes from Xide in the western Yangtze Block, South China: New evidence for continental rifting related to the breakup of Rodinia supercontinent. Precambrian Res. 2015, 268, 339-356. [CrossRef]

43. Zhao, G.C.; Cawood, P.A. Precambrian geology of China. Precambrian Res. 2012, 222, 13-54. [CrossRef]

44. Wang, Q.H.; Yang, H.; Yang, D.B.; Xu, W.L. Mid-Mesoproterozoic (similar to $1.32 \mathrm{Ga}$ ) diabase swarms from the western Liaoning region in the northern margin of the North China Craton: Baddeleyite $\mathrm{Pb}-\mathrm{Pb}$ geochronology, geochemistry and implications for the final breakup of the Columbia supercontinent. Precambrian Res. 2014, 254, 114-128. [CrossRef]

45. Dong, Y.P.; Liu, X.M.; Santosh, M.; Zhang, X.N.; Chen, Q.; Yang, C.; Yang, Z. Neoproterozoic subduction tectonics of the northwestern Yangtze Block in South China: Constrains from zircon U-Pb geochronology and geochemistry of mafic intrusions in the Hannan Massif. Precambrian Res. 2011, 189, 66-90. [CrossRef]

46. Dong, Y.P.; Liu, X.M.; Santosh, M.; Chen, Q.; Zhang, X.N.; Li, W.; He, D.F.; Zhang, G.W. Neoproterozoic accretionary tectonics along the northwestern margin of the Yangtze Block, China: Constraints from zircon U-Pb geochronology and geochemistry. Precambrian Res. 2012, 196, 247-274. [CrossRef]

47. Zhao, G.C.; Cawood, P.A. Tectonothermal evolution of the Mayuan assemblage in the Cathaysia Block: Implications for neoproterozoic collision-related assembly of the South China craton. Am. J. Sci. 1999, 299, 309-339. [CrossRef] 
48. Wang, X.L.; Zhou, J.C.; Griffin, W.L.; Wang, R.C.; Qiu, H.S.; O’Reilly, S.Y.; Xu, X.S.; Liu, X.M.; Zhang, G.L. Detrital zircon geochronology of Precambrian basement sequences in the Jiangnan orogen: Dating the assembly of the Yangtze and Cathaysia Blocks. Precambrian Res. 2007, 159, 117-131. [CrossRef]

49. Wang, L.J.; Griffin, W.L.; Yu, J.H.; O’Reilly, S.Y. Precambrian crustal evolution of the Yangtze Block tracked by detrital zircons from Neoproterozoic sedimentary rocks. Precambrian Res. 2010, 177, 131-144. [CrossRef]

50. Yan, D.P.; Zhou, M.F.; Song, H.L.; Wang, X.W.; Malpas, J. Origin and tectonic significance of a Mesozoic multi-layer over-thrust system within the Yangtze Block (South China). Tectonophysics 2003, 361, 239-254. [CrossRef]

51. Greentree, M.R.; Li, Z.X.; Li, X.H.; Wu, H.C. Late Mesoproterozoic to earliest Neoproterozoic basin record of the Sibao orogenesis in western South China and relationship to the assembly of Rodinia. Precambrian Res. 2006, 151, 79-100. [CrossRef]

52. Chen, W.T.; Zhou, M.F.; Zhao, X.F. Late Paleoproterozoic sedimentary and mafic rocks in the Hekou area, SW China: Implication for the reconstruction of the Yangtze Block in Columbia. Precambrian Res. 2013, 231, 61-77. [CrossRef]

53. Zhou, G.Y.; Wu, Y.B.; Gao, S.; Yang, J.Z.; Zheng, J.P.; Qin, Z.W.; Wang, H.; Yang, S.H. The 2.65 Ga A-type granite in the northeastern Yangtze craton: Petrogenesis and geological implications. Precambrian Res. 2015, 258, 247-259. [CrossRef]

54. Qiu, Y.M.; Gao, S.; McNaughton, N.J.; Groves, D.I.; Ling, W. First evidence of $>3.2$ Ga continental crust in the Yangtze craton of South China and its implications for Archean crustal evolution and Phanerozoic tectonics. Geology 2000, 28, 11-14. [CrossRef]

55. Wang, J.; Zhou, X.L.; Deng, Q.; Fu, X.G.; Duan, T.H.; Guo, X.M. Sedimentary successions and the onset of the Neoproterozoic Jiangnan sub-basin in the Nanhua rift, South China. Int. J. Earth Sci. 2015, 104, 521-539. [CrossRef]

56. Jiang, X.; Wang, J.; Cui, X.; Zhuo, J.; Xiong, G.; Lu, J.; Liu, J. Zircon SHRIMP U-Pb geochronology of the Neoproterozoic Chengjiang Formation in central Yunnan Province (SW China) and its geological significance. Sci. China 2012, 55, 1815-1826. [CrossRef]

57. Geng, Y.S.; Yang, C.H.; Du, L.L.; Wang, X.S.; Ren, L.D.; Zhou, X.W. Chronology and tectonic environment of the Tianbaoshan Formation: New evidence from zircon SHRIMP U-Pb age and geochemistry. Geol. Rev. 2007, 53, 556-563.

58. Li, H.K.; Zhang, C.L.; Yao, C.Y.; Xiang, Z.Q. U-Pb zircon age and Hf isotope compositions of Mesoproterozoic sedimentary strata on the western margin of the Yangtze massif. Sci. China 2013, 56, 628-639. [CrossRef]

59. Zhang, C.H.; Gao, L.Z.; Wu, Z.J.; Shi, X.Y.; Yan, Q.R.; Li, D.J. SHRIMP U-Pb zircon age of tuff from the Kunyang group in central Yunnan: Evidence for Grenvillian orogeny in south China. Chin. Sci. Bull. 2007, 52, 1517-1525. [CrossRef]

60. Zhao, X.F.; Zhou, M.F. Fe-Cu deposits in the Kangdian region, SW China: A Proterozoic IOCG (iron-oxide-copper-gold) metallogenic province. Miner. Depos. 2011, 46, 731-747. [CrossRef]

61. Liu, Y. Simultaneous and precise determination of 40 trace elements in rock samples using ICP-MS. Geochimica 1996, 25, 552-558.

62. Wiedenbeck, M.; Alle, P.; Corfu, F.; Griffin, W.L.; Meier, M.; Oberli, F.; Vonquadt, A.; Roddick, J.C.; Speigel, W. 3 Natural Zircon Standards for U-Th-Pb, Lu-Hf, Trace-Element and Ree Analyses. Geostand. Newslett. 1995, 19, 1-23. [CrossRef]

63. Liu, Y.S.; Hu, Z.C.; Gao, S.; Gunther, D.; Xu, J.; Gao, C.G.; Chen, H.H. In situ analysis of major and trace elements of anhydrous minerals by LA-ICP-MS without applying an internal standard. Chem. Geol. 2008, 257, 34-43. [CrossRef]

64. Liu, Y.S.; Gao, S.; Hu, Z.C.; Gao, C.G.; Zong, K.Q.; Wang, D.B. Continental and Oceanic Crust Recycling-induced Melt-Peridotite Interactions in the Trans-North China Orogen: U-Pb Dating, Hf Isotopes and Trace Elements in Zircons from Mantle Xenoliths. J. Petrol. 2010, 51, 537-571. [CrossRef]

65. Ludwig, K.R. Users Manual for ISOPLOT/EX, Version 3: A Geochronological Toolkit for Microsoft Excel; Berkeley Geochronology Center Special Publication: Berkeley, CA, USA, 2003.

66. Wu, F.Y.; Yang, Y.H.; Xie, L.W.; Yang, J.H.; Xu, P. Hf isotopic compositions of the standard zircons and baddeleyites used in U-Pb geochronology. Chem. Geol. 2006, 234, 105-126. [CrossRef]

67. Geng, J.Z.; Li, H.K.; Zhang, J.; Zhou, H.Y.; Li, H.M. Zircon Hf isotope analysis by means of LA-MC-ICP-MS. Geol. Bull. China 2011, 30, 1508-1513. 
68. Machado, N.; Simonetti, A. U-Pb dating and Hf isotopic composition of zircon by laser-ablation-MC-ICP-MS. In Laser-Ablation-ICPMS in the Earth Sciences: Principles and Applications; Sylvester, P., Ed.; ResearchGate: Berlin, Germany, 2001; pp. 121-146.

69. Chu, N.C.; Taylor, R.N.; Chavagnac, V.; Nesbitt, R.W.; Boella, R.M.; Milton, J.A.; German, C.R.; Bayon, G.; Burton, $\mathrm{K}$. Hf isotope ratio analysis using multi-collector inductively coupled plasma mass spectrometry: An evaluation of isobaric interference corrections. J. Anal. At. Spectrom. 2002, 17, 1567-1574. [CrossRef]

70. Iizuka, T.; Hirata, T. Improvements of precision and accuracy in in situ Hf isotope microanalysis of zircon using the laser ablation-MC-ICPMS technique. Chem. Geol. 2005, 220, 121-137. [CrossRef]

71. Scherer, E.; Munker, C.; Mezger, K. Calibration of the lutetium-hafnium clock. Science 2001, $293,683-687$. [CrossRef] [PubMed]

72. BlichertToft, J.; Albarede, F. The Lu-Hf isotope geochemistry of chondrites and the evolution of the mantle-crust system. Earth Planet. Sci. Lett. 1997, 148, 243-258. [CrossRef]

73. Nowell, G.M.; Kempton, P.D.; Noble, S.R.; Fitton, J.G.; Saunders, A.D.; Mahoney, J.J.; Taylor, R.N. High precision Hf isotope measurements of MORB and OIB by thermal ionisation mass spectrometry: Insights into the depleted mantle. Chem. Geol. 1998, 149, 211-233. [CrossRef]

74. Griffin, W.L.; Pearson, N.J.; Belousova, E.; Jackson, S.E.; van Achterbergh, E.; O’Reilly, S.Y.; Shee, S.R. The Hf isotope composition of cratonic mantle: LAM-MC-ICPMS analysis of zircon megacrysts in kimberlites. Geochim. Cosmochim. Acta 2000, 64, 133-147. [CrossRef]

75. Belousova, E.A.; Griffin, W.L.; O’Reilly, S.Y.; Fisher, N.I. Igneous zircon: Trace element composition as an indicator of source rock type. Contrib. Mineral. Petrol. 2002, 143, 602-622. [CrossRef]

76. Hoskin, P.W.O. Patterns of chaos: Fractal statistics and the oscillatory chemistry of zircon. Geochim. Cosmochim. Acta 2000, 64, 1905-1923. [CrossRef]

77. Gao, X.Y.; Zhang, Q.Q.; Zheng, Y.F.; Chen, Y.X. Petrological and zircon evidence for the Early Cretaceous granulite-facies metamorphism in the Dabie orogen, China. Lithos 2017, 284, 11-29. [CrossRef]

78. Rubatto, D. Zircon trace element geochemistry: Partitioning with garnet and the link between U-Pb ages and metamorphism. Chem. Geol. 2002, 184, 123-138. [CrossRef]

79. Schaltegger, U.; Fanning, C.M.; Gunther, D.; Maurin, J.C.; Schulmann, K.; Gebauer, D. Growth, annealing and recrystallization of zircon and preservation of monazite in high-grade metamorphism: Conventional and in-situ $\mathrm{U}-\mathrm{Pb}$ isotope, cathodoluminescence and microchemical evidence. Contrib. Mineral. Petrol. 1999, 134, 186-201. [CrossRef]

80. Sun, S.S.; McDonough, W.F. Chemical and isotopic systematics of oceanic basalts: Implications for mantle composition and processes. In Magmatism in the Ocean Basins; Saunders, A.D., Norry, M.J., Eds.; Geological Society, London Special Publication: London, UK, 1989; Volume 32, pp. 313-345.

81. Winchester, J.A.; Floyd, P.A. Geochemical Discrimination of Different Magma Series and Their Differentiation Products Using Immobile Elements. Chem. Geol. 1977, 20, 325-343. [CrossRef]

82. Miyashiro, A. Volcanic Rock Series in Island Arcs and Active Continental Margins. Am. J. Sci. 1974, 274, 321-355. [CrossRef]

83. George, R.; Turner, S.; Hawkesworth, C.; Morris, J.; Nye, C.; Ryan, J.; Zheng, S.H. Melting processes and fluid and sediment transport rates along the Alaska-Aleutian arc from an integrated U-Th-Ra-Be isotope study. J. Geophys. Res. 2003, 108, 2252. [CrossRef]

84. Zheng, Y.F.; Zhao, Z.F.; Wu, Y.B.; Zhang, S.B.; Liu, X.M.; Wu, F.Y. Zircon U-Pb age, Hf and O isotope constraints on protolith origin of ultrahigh-pressure eclogite and gneiss in the Dable orogen. Chem. Geol. 2006, 231, 135-158. [CrossRef]

85. Wu, R.X.; Zheng, Y.F.; Wu, Y.B.; Zhao, Z.F.; Zhang, S.B.; Liu, X.M.; Wu, F.Y. Reworking of juvenile crust: Element and isotope evidence from Neoproterozoic granodiorite in South China. Precambrian Res. 2006, 146, 179-212. [CrossRef]

86. Sun, W.H.; Zhou, M.F. The similar to 860-Ma, cordilleran-type guandaoshan dioritic pluton in the Yangtze block, SW China: Implications for the origin of neoproterozoic magmatism. J. Geol. 2008, 116, 238-253. [CrossRef]

87. Fan, H.P.; Zhu, W.G.; Li, Z.X.; Zhong, H.; Bai, Z.J.; He, D.F.; Chen, C.J.; Cao, C.Y. Ca. 1.5 Ga mafic magmatism in South China during the break-up of the supercontinent Nuna/Columbia: The Zhuqing Fe-Ti-V oxide ore-bearing mafic intrusions in western Yangtze Block. Lithos 2013, 168, 85-98. [CrossRef] 
88. Chen, R.X.; Zheng, Y.F.; Xie, L.W. Metamorphic growth and recrystallization of zircon: Distinction by simultaneous in-situ analyses of trace elements, $\mathrm{U}-\mathrm{Th}-\mathrm{Pb}$ and $\mathrm{Lu}-\mathrm{Hf}$ isotopes in zircons from eclogite-facies rocks in the Sulu orogen. Lithos 2010, 114, 132-154. [CrossRef]

89. Shen, W.Z.; Li, H.M.; Xu, S.J.; Wang, R.C. U-Pb chronological study of zircons from the Huangcaoshan and Xiasuozi granites in the western margin of Yangtze Plate. Geol. J. China Univ. 2000, 6, 412-416.

90. Zhuo, J.W.; Jiang, X.S.; Wang, J.; Cui, X.Z.; Xiong, G.Q.; Lu, J.Z.; Liu, J.H.; Ma, M.Z. Opening time and filling pattern of the Neoproterozoic Kangdian Rift Basin, western Yangtze Continent, South China. Sci. China 2013, 56, 1664-1676. [CrossRef]

91. Ma, G.; Li, H.; Zhang, Z. An investigation of the age limits of the Sinian System in South China. Geol. Sci. 1984, 8, 1-29.

92. Wood, D.A.; Joron, J.L.; Treuil, M. Re-Appraisal of the Use of Trace-Elements to Classify and Discriminate between Magma Series Erupted in Different Tectonic Settings. Earth Planet. Sci. Lett. 1979, 45, 326-336. [CrossRef]

93. Polat, A.; Hofmann, A.W.; Rosing, M.T. Boninite-like volcanic rocks in the 3.7-3.8 Ga Isua greenstone belt, West Greenland: Geochemical evidence for intra-oceanic subduction zone processes in the early Earth. Chem. Geol. 2002, 184, 231-254. [CrossRef]

94. Wilson, M. Igneous Petrogenesis: A Global Tectonic Approach; Chapman \& Hall: London, UK, 1989; p. 466.

95. Mahoney, J.J.; Coffin, M.F. Large Igneous Provinces: Continental, Oceanic, and Planetary Flood Volcanism; American Geophysical Union: Washington, DC, USA, 1997; Volume 100.

96. Pearce, J.A.; Norry, M.J. Petrogenetic implications of $\mathrm{Ti}, \mathrm{Zr}, \mathrm{Y}$, and $\mathrm{Nb}$ variations in volcanic rocks. Contrib. Mineral. Petrol. 1979, 69, 33-47. [CrossRef]

97. Tiepolo, M.; Bottazzi, P.; Foley, S.F.; Oberti, R.; Vannucci, R.; Zanetti, A. Fractionation of Nb and Ta from Zr and Hf at Mantle Depths: The Role of Titanian Pargasite and Kaersutite. J. Petrol. 2001, 42, 221-232. [CrossRef]

98. Tiepolo, M.; Vannucci, R.; Bottazzi, P.; Oberti, R.; Zanetti, A.; Foley, S. Partitioning of rare earth elements, Y, $\mathrm{Th}, \mathrm{U}$, and $\mathrm{Pb}$ between pargasite, kaersutite, and basanite to trachyte melts: Implications for percolated and veined mantle. Geochem. Geophys. Geosyst. 2000, 1. [CrossRef]

99. Liu, L.; Yang, X.Y.; Santosh, M.; Aulbach, S.; Zhou, H.Y.; Geng, J.Z.; Sun, W.D. Neoproterozoic intraplate crustal accretion on the northern margin of the Yangtze Block: Evidence from geochemistry, zircon SHRIMP $\mathrm{U}-\mathrm{Pb}$ dating and Hf isotopes from the Fuchashan Complex. Precambrian Res. 2015, 268, 97-114. [CrossRef]

100. Zhang, S.B.; Zheng, Y.F. Formation and evolution of Precambrian continental lithosphere in South China. Gondwana Res. 2013, 23, 1241-1260. [CrossRef]

101. Zheng, J.P.; Griffin, W.L.; O’Reilly, S.Y.; Zhang, M.; Pearson, N.; Pan, Y.M. Widespread Archean basement beneath the Yangtze craton. Geology 2006, 34, 417-420. [CrossRef]

102. Zhang, S.B.; Zheng, Y.F.; Wu, Y.B.; Zhao, Z.F.; Gao, S.; Wu, F.Y. Zircon U-Pb age and Hf isotope evidence for $3.8 \mathrm{Ga}$ crustal remnant and episodic reworking of Archean crust in South China. Earth Planet. Sci. Lett. 2006, 252, 56-71. [CrossRef]

103. Zhang, S.B.; Zheng, Y.F.; Wu, Y.B.; Zhao, Z.F.; Gao, S.; Wu, F.Y. Zircon isotope evidence for $\geq 3.5$ Ga continental crust in the Yangtze craton of China. Precambrian Res. 2006, 146, 16-34. [CrossRef]

104. Zhang, S.B.; Zheng, Y.F.; Wu, Y.B.; Zhao, Z.F.; Gao, S.; Wu, F.Y. Zircon U-Pb age and Hf-O isotope evidence for Paleoproterozoic metamorphic event in South China. Precambrian Res. 2006, 151, 265-288. [CrossRef]

105. Barth, M.G.; McDonough, W.F.; Rudnick, R.L. Tracking the budget of $\mathrm{Nb}$ and $\mathrm{Ta}$ in the continental crust. Chem. Geol. 2000, 165, 197-213. [CrossRef]

106. Weaver, B.L. The origin of ocean island basalt end member compositions: Trace element and isotopic constraints. Earth Planet. Sci. Lett. 1991, 104, 381-397. [CrossRef]

107. Rubatto, D.; Hermann, J. Zircon formation during fluid circulation in eclogites (Monviso, Western Alps): Implications for $\mathrm{Zr}$ and $\mathrm{Hf}$ budget in subduction zones. Geochim. Cosmochim. Acta 2003, 67, 2173-2187. [CrossRef]

108. Rubatto, D.; Hermann, J.; Berger, A.; Engi, M. Protracted fluid-induced melting during Barrovian metamorphism in the Central Alps. Contrib. Mineral. Petrol. 2009, 158, 703-722. [CrossRef]

109. Hoskin, P.W.O.; Schaltegger, U. The composition of zircon and igneous and metamorphic petrogenesis. Geochim. Cosmochim. Acta 2003, 53, 27-62. [CrossRef] 
110. Peck, W.H.; Valley, J.W.; Wilde, S.A.; Graham, C.M. Oxygen isotope ratios and rare earth elements in 3.3 to 4.4 Ga zircons: Ion microprobe evidence for high delta O-18 continental crust and oceans in the Early Archean. Geochim. Cosmochim. Acta 2001, 65, 4215-4229. [CrossRef]

111. Watson, E.B.; Harrison, T.M. Zircon Saturation Revisited-Temperature and Composition Effects in a Variety of Crustal Magma Types. Earth Planet. Sci. Lett. 1983, 64, 295-304. [CrossRef]

112. Wang, X.C.; Li, Z.X.; Li, J.; Pisarevsky, S.A.; Wingate, M.T.D. Genesis of the 1.21 Ga Marnda Moorn large igneous province by plume-lithosphere interaction. Precambrian Res. 2014, 241, 85-103. [CrossRef]

113. Wedepohl, K.H. The Composition of the Continental-Crust. Geochim. Cosmochim. Acta 1995, 59, 1217-1232. [CrossRef]

114. Hergt, J.M.; Peate, D.W.; Hawkesworth, C.J. The Petrogenesis of Mesozoic Gondwana Low-Ti Flood Basalts. Earth Planet. Sci. Lett. 1991, 105, 134-148. [CrossRef]

115. Hawkesworth, C.J.; Lightfoot, P.C.; Fedorenko, V.A.; Blake, S.; Naldrett, A.J.; Doherty, W.; Gorbachev, N.S. Magma Differentiation and Mineralization in the Siberian Continental Flood Basalts. Lithos 1995, 34, 61-88. [CrossRef]

116. Li, X.H.; Li, Z.X.; Wingate, M.T.D.; Chung, S.L.; Liu, Y.; Lin, G.C.; Li, W.X. Geochemistry of the 755 Ma Mundine Well dyke swarm, northwestern Australia: Part of a Neoproterozoic mantle superplume beneath Rodinia? Precambrian Res. 2006, 146, 1-15. [CrossRef]

117. Wang, X.C.; Wilde, S.A.; Xu, B.; Pang, C.J. Origin of arc-like continental basalts: Implications for deep-Earth fluid cycling and tectonic discrimination. Lithos 2016, 261, 5-45. [CrossRef]

118. Pearce, J.A. Trace element characteristics of lavas from destructive plate boundaries. In Andesites: Orogenic Andesites and Related Rocks; Thorpe, R.S., Ed.; Wiley: Chichester, UK, 1982; pp. 528-548.

119. Wang, Y.L. Th/Hf-Ta/Hf identification of tectonic setting of basalts. Acta Petrol. Sin. 2001, 17, $413-421$.

120. Shervais, J.W. Ti-V Plots and the Petrogenesis of Modern and Ophiolitic Lavas. Earth Planet. Sci. Lett. 1982, 59, 101-118. [CrossRef]

121. Pearce, J.A. A user's guide to basalt discrimination diagrams. In Trace Element Geochemistry of Volcanic Rocks: Applications for Massive Sulphide Exploration Geological Association of Canada, Short Course Notes; Wyman, D.A., Ed.; Geological Association of Canada: St. John's, NL, Canada, 1996.

122. Pearce, J.A.; Cann, J.R. Tectonic Setting of Basic Volcanic-Rocks Determined Using Trace-Element Analyses. Earth Planet. Sci. Lett. 1973, 19, 290-300. [CrossRef]

123. Li, Z.X.; Li, X.H.; Zhou, H.W.; Kinny, P.D. Grenvillian continental collision in south China: New SHRIMP $\mathrm{U}-\mathrm{Pb}$ zircon results and implications for the configuration of Rodinia. Geology 2002, 30, 163-166. [CrossRef]

124. Li, Z.X.; Wartho, J.A.; Occhipinti, S.; Zhang, C.L.; Li, X.H.; Wang, J.; Bao, C.M. Early history of the eastern Sibao Orogen (South China) during the assembly of Rodinia: New mica Ar-40/Ar-39 dating and SHRIMP U-Pb detrital zircon provenance constraints. Precambrian Res. 2007, 159, 79-94. [CrossRef]

125. Xia, L.Q.; Xia, Z.C.; Xu, X.Y.; Li, X.M.; Ma, Z.P. Mid-Late Neoproterozoic rift-related volcanic rocks in China: Geological records of rifting and break-up of Rodinia. Geosci. Front. 2012, 3, 375-399. [CrossRef]

126. Huang, X.L.; Xu, Y.G.; Li, X.H.; Li, W.X.; Lan, J.B.; Zhang, H.H.; Liu, Y.S.; Wang, Y.B.; Li, H.Y.; Luo, Z.Y.; et al. Petrogenesis and tectonic implications of Neoproterozoic, highly fractionated A-type granites from Mianning, South China. Precambrian Res. 2008, 165, 190-204. [CrossRef]

127. Huang, X.L.; Xu, Y.G.; Lan, J.B.; Yang, Q.J.; Luo, Z.Y. Neoproterozoic adakitic rocks from Mopanshan in the western Yangtze Craton: Partial melts of a thickened lower crust. Lithos 2009, 112, 367-381. [CrossRef]

128. Cui, X.Z.; Jiang, X.S.; Wang, J.; Zhuo, J.W.; Wu, H.; Xiong, G.Q.; Lu, J.Z.; Deng, Q.; Jiang, Z.F. Filling Sequence and evolution model of the Neoproterozoic rift basin in central Yunnan province, South China: Response to the breakup of Rodinia supercontinent. Acta Sedimentol. Sin. 2014, 32, 399-409.

129. Chorowicz, J. The East African rift system. J. Afr. Earth Sci. 2005, 43, 379-410. [CrossRef]

130. Turner, N.J.; Black, L.P.; Kamperman, M. Dating of Neoproterozoic and Cambrian orogenies in Tasmania. Aust. J. Earth Sci. 1998, 45, 789-806. [CrossRef]

131. Preiss, W.V. The Adelaide Geosyncline of South Australia and its significance in Neoproterozoic continental reconstruction. Precambrian Res. 2000, 100, 21-63. [CrossRef]

132. Jefferson, C.W.; Parrish, R.R. Late Proterozoic stratigraphy, U-Pb zircon ages, and rift tectonics, Mackenzie Mountains, northwestern Canada. Can. J. Earth Sci. 1989, 26, 1784-1801. [CrossRef] 
133. Miyazaki, T.; Kagami, H.; Shuto, K.; Morikiyo, T.; Mohan, V.R.; Rajasekaran, K.C. Rb-Sr geochronology, Nd-Sr isotopes and whole rock geochemistry of Yelagiri and Sevattur syenites, Tamil Nadu, South India. Gondwana Res. 2000, 3, 39-53. [CrossRef]

134. Santosh, M.; Iyer, S.S.; Vasconcellos, M.B.A.; Enzweiler, J. Late Precambrian Alkaline Plutons in Southwest India-Geochronologic and Rare-Earth Element Constraints on Pan-African Magmatism. Lithos 1989, 24, 65-79. [CrossRef]

135. Hoffman, P.F.; Hawkins, D.P.; Isachsen, C.E.; Bowring, S.A. Precise U-Pb zircon ages for early Damaran magmatism in the Summas Mountains and Welwitschia Inlier, northern Damara belt, Namibia. Commun. Geol. Surv. Namib. 1996, 11, 47-52.

136. Zhang, C.L.; Zou, H.B.; Li, H.K.; Wang, H.Y. Tectonic framework and evolution of the Tarim Block in NW China. Gondwana Res. 2013, 23, 1306-1315. [CrossRef]

(C) 2018 by the authors. Licensee MDPI, Basel, Switzerland. This article is an open access article distributed under the terms and conditions of the Creative Commons Attribution (CC BY) license (http://creativecommons.org/licenses/by/4.0/). 